\title{
IN DEFENCE OF CLASS
}

\section{A CRITIQUE OF RECENT REVISIONIST WRITING UPON THE NINETEENTH-CENTURY ENGLISH WORKING CLASS*}

The view that class occupied a central place in the lives of nineteenthcentury English workers has recently come under increasing criticism within the fields of labour and social history. Joyce (1980), Stedman Jones (1982 and 1983), Calhoun (1982) and Glen (1984) ${ }^{1}$ are prominent examples of scholars who have proclaimed, albeit to varying degrees and with different points of emphasis, that at various times during the nineteenth century workers were far less motivated by class than claimed by Edward and Dorothy Thompson, Hobsbawm and likeminded historians. ${ }^{2}$ Criticisms of this latter group of historians are, of course, not new. ${ }^{3}$ Nevertheless it may be suggested that the recent criticisms of class do possess two distinguishing characteristics. Firstly, they have surely gathered a momen-

* Various drafts of this article have been read by Leon Fink, John Saville, Noel Thompson, Colin Barker, Brian Collier, Steve Jones, John Walton, Peter Taylor, Joan Smith, Steve Jefferys, Patrick Joyce and Julie Greene. I am very grateful for their comments and suggestions. I have also benefitted greatly from the comments offered by students in Manchester and New Haven.

1 P. Joyce, Work, Society and Politics: The Culture of the Factory in Later Victorian England (Brighton, 1980); G. Stedman Jones, "The Language of Chartism", in: The Chartist Experience: Studies in Working-Class Radicalism and Culture, 1830-1860, ed. by J. Epstein and D. Thompson (London, 1982); id., "Rethinking Chartism", in Languages of Class: Studies in English Working-Class History 1832-1982 (Cambridge, 1983); C. Calhoun, The Question of Class Struggle: Social Foundations of Popular Radicalism during the Industrial Revolution (Chicago, 1982); R. Glen, Urban Workers in the Early Industrial Revolution (London, 1983). See also A. E. Musson, British Trade Unions 1800-1875 (London, 1972).

2 The first chapter in Glen, Urban Workers in the Early Industrial Revolution, summarises recent debates concerning class in early-nineteenth-century England. See also E. P. Thompson, The Making of the English Working Class (Harmondsworth, 1980), Preface and Conclusion; E. J. Hobsbawm, Worlds of Labour (London, 1984); D. Thompson, The Chartists (London, 1984). See also the essays by Sykes, Behagg and Epstein in The Chartist Experience for an emphasis upon the class character of Chartism.

3 Thus, for example, the "generous but critical reception" given to Edward Thompson's book in the 1960's academic press. See Thompson, The Making, p. 917. 
tum and a degree of influence within labour and social history which the criticisms of the 1960's (especially the positivist-based critiques of Edward Thompson's view of class) failed to achieve. (This change is, in part, related to the defeats and retreats suffered by the labour movement under Thatcherism, and the current intellectual and political re-assessment of the historical strength of class-consciousness within the British working class. ${ }^{4}$ ) Secondly, the criticisms of the 1980's issue from a much wider range of theoretical perspectives than was the case during the 1960's. It is no longer a case of the defenders of the class-consciousness of workers being confronted solely, or even mainly, by positivist-minded critics, but by scholars deriving sustenance from wide and varied "positions" and sources. This point is reflected in, for example, Stedman Jones's great debts to Althusser and Saussure, Calhoun's to a "socio-structural" approach to social reality, and Joyce's to the "total history" perspective of the Annalistes and others. ${ }^{5}$

The purpose of this article is not to provide a general review of the work of the various critics of class mentioned above. Rather, a more precise task is attempted: to develop a critique of Gareth Stedman Jones's revisionist approach to labour history and the question of class, as revealed in his two essays on Chartism, "The Language of Chartism" (1982, hereafter LCh) and "Rethinking Chartism" (1983, hereafter RCh). In these essays Stedman Jones rejects the historiographically dominant "social" approach to Chartism in favour of a political interpretation. The latter sees Chartism not as a social, class-based movement, appealing primarily to an economically defined and economically exploited working class, but as a movement in which politics reigned supreme, in which exploitation was explained in

4 The "halting" of the "forward march of labour" has certainly been of central importance in Stedman Jones's historical questioning of class. See his Languages of Class, op. cit., p. 1 and Introduction. Political changes have, at least at the conscious level of intention, informed the work of Calhoun, Glen and Joyce to a much lesser extent.

5 From his "objective" socio-structural vantage point, Calhoun has directed (or, more "objectively", misdirected) his fire at Edward Thompson's alleged preoccupation with culture and consciousness ("culturalism") at the expense of the "objective" structural determinations of class and social reality. Despite his acknowledged debt to Thompson's anti-reductionist standpoint, Stedman Jones also claims that Thompson's central notion of "experience" is subjectivist in character. Stedman Jones much prefers Althusser's concept of hidden structure. I would suggest that Thompson is fully alive to the importance of structure, is suspicious of the notion of permanently hidden structures (i.e. beyond the perception of mere mortals, if not academics), and offers a convincing defence of his historical practice. For such matters see Calhoun, The Question of Class Struggle, op. cit., pp. x, 22, 33; Stedman Jones, Languages of Class, pp. 12, 20; E. P. Thompson, "The Politics of Theory", in: People's History and Socialist Theory, ed. by R. Samuel (London, 1981); and the excellent article by E. M. Wood, "E. P. Thompson and His Critics", in: Studies in Political Economy, No 9 (1982). For "total history" see Joyce, Work, Society and Politics, op. cit., p. xxiv. 
political terms, and with its main appeal to the politically excluded and economically "productive" of all social strata. Thus, in Stedman Jones's opinion, Chartism constitutes a classic, perhaps the classic, example of the ways in which a long line of historians and others have falsely inflated the class-consciousness of modern English workers.

I will undertake a detailed examination of Stedman Jones's arguments shortly. For the moment it is important to briefly indicate the ways in which critics have responded to Stedman Jones's essays, and to outline the thesis propounded in this article. Reviewers of Stedman Jones's essays on Chartism have tended to concentrate their attentions on four aspects of his work: the nature and study of words and language; the contribution made by language to the construction of social meaning; the ideological character of Chartism; and the relationships between, on the one hand, language and ideas (especially political ideas) and, on the other, economic and social levels and practices within social formations. The prime concern of this article rests with the third and fourth aspects. However, it should be noted at the outset that reviewers such as Robbie Gray and John Foster have stressed the problematical nature of Stedman Jones's treatment of the first two aspects. According to these critics, Stedman Jones's "non-referential" approach to language amounts to little more than a highly formalised, literal and narrow interpretation of words and ideas rather than to an investigation of the far more exacting and potentially fruitful areas of the ways in which social meaning is constructed, and the role of language in that construction. In Foster's opinion, Stedman Jones ignores "the crucial nexus of social practice, language and consciousness", and the ambiguities, complexities and multi-layered meanings of historically specific languages are not afforded their due attention. ${ }^{6}$

6 Indeed, it may be justifiably argued that Stedman Jones does not really offer a poststructuralist reading of language at all, but rather that his overriding concern rests with the history of radicalism as a body of ideas; and that such ideas are approached in the manner of conventional intellectual history, complete with its insufficient attention to context and complexity of meaning. As Karen Sawislak has noted, "Because he is convinced that the Chartists said only what they meant, and meant only what they (literally) said, Stedman Jones sees Chartism only as a political movement with little to do with the productive system" ("Rethinking Chartism", discussion paper, Yale University, 1987). Stedman Jones could have clarified his methodological concerns by providing an outline of the theories of Saussure and the post-structuralists; and, as Robbie Gray observes in his subtle and perceptive review, by acknowledging that post-structuralist work on language and reality "is itself a field of debate, rather than a firmly constituted method which historians can adopt" (R. Gray, "The Deconstructing of the English Working Class", in: Social History, XI (1986), p. 367). In reference to the above issues, see J. Foster, "The Declassing of Language”, in: New Left Review, No 150 (1985), esp. p. 43. 
I will return to such matters at various points during this article, but it is now necessary to turn to our key concerns, the ideological character of Chartism and interactions between ideas and material existence. Following the general lines of criticism laid down by Paul Pickering and James Epstein, ${ }^{7}$ I will both defend Chartism as a social, class-based movement and suggest that in his stress upon the political nature of Chartism Stedman Jones greatly underestimates the influence exerted by economic and social factors upon the political ideas of the movement. More generally, Stedman Jones's awful dread of economic reductionism leads not to materialism, but to an unsatisfactory idealism. Let us proceed to a closer examination of his arguments.

\section{Chartism as a political movement}

A prime target of Stedman Jones's revisionism is the conventional picture of Chartism as a social movement. In his opinion there have been many variants of the social interpretation, expressed by historians and others from a wide range of ideological perspectives. It is, however, the social interpretation in its class-based forms (Chartism as the political arm of the first modern class-conscious industrial proletariat: Engels and Lenin; or Chartism as the flowering of early-nineteenth-century working-class consciousness: the Thompsoms and others) which demands specific and urgent correction. ${ }^{8}$ But whatever its particular form, it is the social approach as a whole, maintains Stedman Jones, which has dominated the historiography of the movement and which, in the interests of historical accuracy and correct understanding, must be refuted. For an emphasis upon the "social" has frequently been to the neglect of the platform and programme of Chartism. Instead of listening to the actual language of the Chartists, many contemporaries and historians have, according to Stedman Jones, operated

7 P. A. Pickering, "Class without Words: Symbolic Communication in the Chartist Movement", in: Past \& Present, No 112 (1986); J. Epstein, "Rethinking the Categories of Working-Class History", in: Labour / Le Travail, No 18 (1986).

8 Stedman Jones's criticisms of Edward Thompson's view of radicalism and Chartism are brief but unmistakable, Languages of Class, pp. 16-20. Somewhat surprisingly, Dorothy Thompson's work on Chartism is not directly addressed in either LCh or RCh. Presumably, as an advocate of the "class" character of Chartism, Dorothy Thompson is to be placed in the "social" camp. Simultaneously, given her close attention to the politics of class, Dorothy, like Edward Thompson, Jim Epstein and Robert Sykes, is not to be seen as a reductionist of an economic kind. However, the implication in Stedman Jones's work is that the Thompsons largely fail to apply their aversion to economic reductionism to the study of language, the latter being seen far too unproblematically as the expression of "experience". See Thompson, The Making, pp. 782, 887-915; D. Thompson, The Early Chartists (London, 1971), Introduction. 
with predetermined notions of class or occupational consciousness (of what handloom weavers, factory operatives and others must have thought as depressed occupations and/or members of a perceived class), and have accordingly attributed such notions to the Chartists without sufficient attention to the language of Chartism itself.

Thus there has occurred "general neglect of the specific political and ideological form within which [. . . ] mass discontent was expressed and the consequent tendency to elide the Chartist language of class with a range of Marxist or sociological notions of class consciousness" (LCh, p. 5). The presence of class in the political consciousness of the Chartists, indeed of much of the modern British working class, has, declares Stedman Jones, all too often not been adequately substantiated in empirical form by historians and others, but simply inferred or "read off", in commonsensical and economistic ways, from class as a "structural position within productive relations". ${ }^{9}$ The same problems of inference and reductionism have also marred the study of language. Far from being seen as a force which is present in the actual construction of reality, the language of Chartism has, claims Stedman Jones, usually been treated by historians as the simple expression of an anterior social reality, "social being". ${ }^{10}$

It is the firm intention of Stedman Jones to correct the faults implicit in the social approach to both Chartism and modern working-class history. A priori notions of working-class consciousness are to be eschewed and proper attention paid to actual language and historical context. "An analysis of Chartist ideology must start from what Chartists actually said or wrote", insists Stedman Jones (LCh, p. 6), and the language and politics of Chartism approached not as passive reflections of the "social", but as subjects in their own right, to be afforded their due "autonomous weight" (RCh, p. 107). And "if the interpretation of the language and politics is freed from a priori social inferences, it then becomes possible to establish a far closer and more precise relationship between ideology and activity than is conveyed in the standard picture of the movement." (LCh, p. 6) Stedman Jones's ultimate aim is not, however, to replace a social by a linguistic interpretation, but rather to re-examine the ways in which the "linguistic" and the "social" interact. The specific rethinking of Chartism is thus part of a larger project of rethinking Marxist historiography - of exploring the degrees of autonomy enjoyed by language and politics, of disputing "any simple notion of the determination of consciousness by social being", and

9 Stedman Jones, Languages of Class, p. 2.

10 Ibid., p. 20. 
of highlighting the complexity of social practice. ${ }^{11}$ And in "harnessing [. . . ] elementary insights derived from theories of language to problems of substantive historical interpretation" Stedman Jones does not seek to "obliterate the significance of the work of the social historian", but to locate its significance "in a different perspective". ${ }^{12}$

Stedman Jones's examination of the language of popular radicalism during the early and mid 1830's (as revealed especially in the Poor Man's Guardian), and of the later language of the Chartist leadership and the Northern Star, produces a number of novel and challenging conclusions. Most significant is the claim that Chartism was primarily a political rather than a social movement, with a political rather than an economic explanation of exploitation and misery, and having an appeal not mainly to an economically exploited working class divorced from ownership of the means of production, but rather to a wider audience of the "productive" members of society (which included workers and "fair" employers), who were the victims of monopoly political power and corruption, and to all the politically unrepresented. ${ }^{13}$ As such, maintains Stedman Jones, Chartism, far from being "the first manifestation of a modern working-class movement", was not a novel form of protest. In contrast to the views of Engels, Lenin and others, Stedman Jones emphasises continuity. He writes: "As a secular phenomenon, Chartism was the last, most prominent, and most desperate - though not perhaps the most revolutionary - version of a radical critique of society, which had enjoyed an almost continuous existence since the 1760s and 1770s." (RCh, p. 168)

According to this critique, the miseries of the "People" or the "nation" derived neither from a particular mode of production nor from factors

11 It might be assumed, therefore, that Stedman Jones is not abandoning economism in favour of idealism, but is intent upon the construction of a sophisticated materialism. However, many of Stedman Jones's other references to such matters are far less clear and unambiguous than the passages quoted in the text. For example, in Languages of Class he seems at various points to seriously doubt: the very nature of material determination ( $p$. 7 ); the significance of "class" as an "ontological reality" (preferring, instead, to treat"class" as a "discursive" reality, and to "explain languages of class from the nature of politics rather than the character of politics from the nature of class", p. 8); and the extent to which material factors exerted any significant influence upon the language of popular radicalism ("But the form in which these discontents were addressed cannot be understood in terms of the consciousness of a particular social class, since the form pre-existed any independent action by such a class and did not significantly change in response to it", $\mathrm{RCh}, \mathrm{p} .95$, italics added). Indeed, I will argue that in practice Stedman Jones improperly releases the political ideas of the Chartists from their material influences and limits, affords such ideas inflated autonomy, and thus embraces idealism.

12 Ibid., p. 24.

13 LCh, pp. 13, 15-16, 20, 23, 31, 45; RCh, pp. 153-54. 
inscribed in the general economic system, but from the exclusion of the majority from the vote and the concentration of political power in the monopolistic and grasping hands of landlords, tithe-holders, fund-holders, bankers and middlemen. Rent and interest were indeed to be condemned as the spoils of exploitation by "unproductive" landlords, speculators and the like, and the "Ricardian socialists" Gray, Thompson, Hodgskin and Bray (RCh, pp. 133-47; LCh, pp. 20-23) did develop an increasingly popular theory of capitalist exploitation in exchange, with the capitalist, as middleman, unfairly cornering the market and depriving the artisan of the full fruits of his product. But, insists Stedman Jones, neither the Ricardian socialists nor popular radicals in general located capitalist exploitation within the sphere of production. Indeed, for all radicals the various economic and social ills of the "People" were to be traced to their true political roots: monopoly economic power was believed to be the result, rather than the cause, of monopoly political power, and the only real solution for such ills resided, therefore, in political action. Thus Stedman Jones declares:

The critiques to be found in Hodgskin and Gray, and in a more popular form in the Poor Man's Guardian were not of employers, whose antagonistic relation to workers was inscribed within the economic system, but of "capitalists" as parasitic middlemen whose privileged and tyrannical position was an aberration resulting from the monopoly of political and legal power possessed by the propertied governing classes. Whether the critique was directed at tax-eaters, as in the older vision, or more generally at "capitalists" in the newer, the political source and origins of oppression remained equally clear. (LCh, p. 20)

It is the case, continues Stedman Jones, that "there was a shift of emphasis and imagery in the Chartist period". As a result of the movements and experiences of the 1830's - the growing campaign over "factory slavery", opposition to the New Poor Law, trade-union battles, the "betrayal" of 1832, the increased levels of cyclical and technological unemployment, mounting employer "tyranny", and the general hostility of the system to working-class demands - there occurred a hardening of attitudes and a polarisation of interests. By the early 1840's radicalism had become, de facto, the more and more exclusive property of the "working classes", the Chartists no longer trusted the motives of the middle-class reformers, and, especially in the North of England, the factory masters, or "steamlords", were identified as the principal enemies of the workers (LCh, pp. 28-29).

It is, of course, in the above developments that historians have usually detected the growth of class struggle and class-consciousness. Once again, however, Stedman Jones disagrees. For, despite the increasingly working- 
class composition of Chartism and the intensification of social conflict, it would be wrong, claims Stedman Jones, to suggest that "the radical analysis that lay behind the Charter was in the course of displacement by a different and more class-conscious mode of thought." (LCh, p. 30) We are thus informed that the Chartists remained convinced of "the political origin and determination of oppression"; that the "monopolisation of land" (which had "made them 'landless' wage slaves in the first place") continued to be seen as "the prime cause of the misery of the worker, with the monopolisation of money and machinery as secondary derivatives" (LCh, p. 31); and that "the depth and extent of antagonism" towards the "steamlords" should not be allowed to obscure the fact (as has often been the case) that the Chartists did not develop a theory of capitalist exploitation in production, and especially not "a class-based theory of exploitation of a social democratic or Marxist kind" ( $\mathrm{LCh}$, p. 20). It was the "capitalist" as middleman who continued to be attacked. But even in this role the "capitalist" was regarded with a certain amount of ambiguity, being condemned "not on account of his economic role" (being more a slave to, rather than an author of, the competitive economic system of buying cheap and selling dear), but on account of "his political beliefs and social attitudes", being "the willing complier in the tyrannical rule of property" and the supporter of the blatant "class legislation" of the 1830's (LCh, pp. 20-21, 23).

"Unfair" employers were mercilessly criticised, but not employers as such. "Fair" and "honest" employers, such as Fielden, could occupy "a revered place in the radical movement", being living proof that there was "no inherent necessity in the association between employers and Malthusian political economy", and that not all sections of the middle class had become corrupt (LCh, pp. 45-46). Excessive profits were likewise condemned, but not profit itself. Unlike rent and interest, which were perceived as "the product of no labour", "fair" and "honest" profit could be justified in moderation as "the wages of supervision" (LCh, p. 31). Far from having antagonistic interests, the "honest" worker and "honest" employer were, as members of the "producing classes", natural allies against the machinations of the corrupt, parasitical and unrepresentative monopolists of political and (its consequent) economic power. Stedman Jones writes:

What we have here [. . . ] is not a picture of two opposed classes thrown up by a new system of production, in which the role of the employer as manager and controller of the process is a crucial feature of its exploitative character, but rather a harmonious world of production inhabited by masters and men, degraded by the artificial imposition of a political system which sanctions and sustains the extraction of exorbitant interest payments to a purely 
parasitic class of capitalists who garrison every point of exchange. $(\mathrm{RCh}, \mathrm{p}$. 137)

It is, furthermore, significant that "despite the intensity of hostility to the 'steam-producing class' in the Chartist period, no proposal was ever made to take over the mills and expropriate their owners." (RCh, p. 157) Rather, "high wages, short hours, a tax on machinery and renewed access to the land [...] was generally the most that was specifically advocated against the tyranny of the millocrat." (RCh, pp. 157-58)

In sum, given its traditional political character and its "failure" to develop a theory of exploitation in production, Chartism does not, in Stedman Jones's eyes, qualify as a class-based movement. In effect, Stedman Jones is not only opposed to Foster's thesis of revolutionary consciousness, but also to the immensely influential view of the Thompsons that Chartism represented the flowering of a class-consciousness based, in part, upon growing economic antagonisms between workers and their employers. ${ }^{14}$ Stedman Jones is adamant that popular anger was directed not against the economic system as such, but merely against its "abuses", and that such "abuses" had their perceived origins in the political system. ${ }^{15}$ "Before anything further could be conceived", claims Stedman Jones, "the whole labour theory based on natural right would have to be jettisoned" (LCh, p. 34); only within Marxism and certain kinds of socialism would it appear "unnatural" or exploitative for the capitalist to receive a reward for his supervision and management in the form of profit.

Political factors are held to be of primary importance not only in the creation and character of Chartism, but also in the movement's decline. Stedman Jones maintains that, mainly as a result of the "vehemence of opposition" to the "class" legislation of the 1830's, the State softened its character during the 1840 's. We are informed that the Mines Act of 1842, the 1842 Budget, the Joint Stock Company Act, the Bank Charter Act and, above all, the Repeal of the Corn Laws signified "the effective raising of the State above the dictates of particular economic interests - whether landlords, financiers or manufacturers" (LCh, p. 51). Furthermore, argues Stedman Jones, the Ten Hours Bill, the increased gains made by skilled trade unionism and the co-operative societies, moves towards State-provided education and discussion of measures to improve the health of towns were indicative both of the more accommodative role of the State and of the

14 Thompson, The Making, pp. 11, 782; Thompson, The Chartists, op. cit., chs 5, 6, 10; Stedman Jones, "Class Struggle and the Industrial Revolution", in Languages of Class, pp. 60-62.

is Stedman Jones, RCh, p. 117; id., "Some Notes on Karl Marx and the English Labour Movement”, in: History Workshop, No 18 (1984). 
enhanced opportunities for the advancement of (albeit unenfranchised) sectors of the working class within the existing system. It is, of course, true that by no means all working-class grievances were resolved by the end of the 1840 's.

The unrepresentative House of Commons, the aristocratic character of the Constitution, the privileged position of the Church and the exclusion of the working classes from the legislature still remained evils about which all radicals could agree.

"But", continues Stedman Jones,

the tight link forged between the oppression of the working classes and the monopoly of political power exercised through the medium of "class legislation" - the essence of Chartist rhetoric- began to loosen. (RCh, pp. 51-52)

Thus by the mid 1840's there had developed a gulf between, on the one hand, Chartism's beliefs that the State was a totally evil and hostile force and that lasting improvement for the "People" was impossible without the prior enactment of the Charter, and, on the other, the lived experience and perceptions of large numbers of the movement's followers. Thus, Stedman Jones writes:

Once, however, the evidence suggested that real reform was possible within the unreformed system, that the State did not wholly correspond to the radical picture and conditions changed in such a way that differences in the fortunes of various trades became clearly visible, despite the identity of their political situation, then radical ideology could be expected to lose purchase over large parts of its mass following. (LCh, p. 15)

A further consequence of the State's softened political practice and "the high moral tone" of the proceedings of Peel's government was that there no longer existed within radical ideology an "independent rationale [. . .] for antagonism towards the middle class as such". Given that popular hostility to the middle class "was not ascribed to their role in production, but to their participation in a corrupt and unrepresentative political system" (ibid.), then, in Stedman Jones's view, the emergence of a more honest and accommodative State greatly weakened the basis of that hostility ( $\mathrm{RCh}, \mathrm{p}$. 177). Demands for independent working-class political action became less compelling and the door was opened to liberal radicalism. In such a way does Stedman Jones locate the key to Chartism's demise not in "ambitious sociological explanations" (of a "labour-aristocratic" or "social control" type), nor in economic developments, but at the political level, in "the changing character and policies of the State - the principal enemy upon whose actions radicals had always found that their credibility depended" (LCh, p. 52). 
Before turning to a critique of Stedman Jones's revisionism, it is worth pausing to note that "The Language of Chartism" and "Rethinking Chartism" offer significant pointers as to the major developments and changes in Stedman Jones's intellectual direction during the past decade. It is, for example, interesting to record that in his 1975 review of John Foster's Class Struggle and the Industrial Revolution Stedman Jones did explain the ebbing of class struggle and the growth of reformism at mid century largely in economic terms, attaching central importance to the growth of a re-stabilised capitalism in which "real" control over production passed, as revealed most prominently in cotton, from worker to employer. ${ }^{16}$ Stedman Jones's review was in agreement with Foster's view that political concessions were also made to workers, but (like Foster) did not afford such concessions explanatory primacy. Indeed, Stedman Jones warned against an exaggerated view of "the concessions associated with liberalization", and maintained that such concessions were "only carried through at a national level in the late 1860 's". ${ }^{17}$ The materialist explanation offered in Stedman Jones's review was, of course, consistent with his belief in "the determinant place of relations of production" within the social formation. ${ }^{18}$ Such a belief has subsequently waned to the extent that in Languages of Class Stedman Jones's scepticism extends to "the character of social determination in itself". The refusal in the essays on Chartism to make "any simple prejudgement about the determining role of the 'social", and the primacy afforded to the "political" constitute the fruits of Stedman Jones's overall change of intellectual direction. ${ }^{19}$

\section{Chartism and class: $A$ defence}

"The Language of Chartism" and "Rethinking Chartism" do not aim to provide an exhaustive account of the language of Chartism. ${ }^{20}$ Stedman Jones generously declares both the selectivity of his focus (which rests largely upon "the public political language of the movement", as seen in radical literature and speeches reported in the radical press) and the limited nature of his research base (which is heavily dependent upon the Poor Man's Guardian, the Northern Star, and the speeches of O'Connor, O'Brien and, to a lesser extent, Harney, McDouall, Leach, Bray and

16 Id., "Class Struggle and the Industrial Revolution", loc. cit., pp. 45-55, 66-74.

17 Ibid., p. 73.

18 Id., Languages of Class, pp. 7, 16.

19 Ibid.

20 "The Language analysed here is largely taken from radical literature and speeches reported in the radical press. [. . .] it is not suggested that this is the only language Chartists employed." LCh, note 10 . 
Gray). He further acknowledges the fact that the "public political" was not the sole kind of language employed by the Chartists, and that "Much further research would be required before a full account of the language of Chartism could be produced." (LCh, note 10) It is, however, at this point that a contradiction arises between the stated intentions and actual practice of Stedman Jones's essays. Despite their confessed limitations and disclaimers to completeness, both essays do, in effect, make claims concerning the language and ideology of Chartism, which are held to be typical of (or at least to be the dominant strand within) Chartism as a whole. In short, large generalisations are erected upon relatively slight, arguably insufficient, empirical foundations. In addition, it may be suggested that Stedman Jones offers a highly selective reading of his source material. One of the major claims of this article is that an "alternative" reading of the very same sources reveals an intensely class-based language, which was at the heart of Chartism, but which is largely overlooked by Stedman Jones.

To reason in the above manner is not, however, to claim that my account of Chartist language and ideology is complete. The focus of this article is also selective, and the conclusions offered must be seen to be provisional and limited in character. My primary focus rests upon the factory districts of Lancashire and Cheshire, and the views of a leading Lancashire Chartist, Peter Murray McDouall, upon questions of poverty, exploitation, class relations and related issues. The attitudes of O'Connor, Ernest Jones, James Leach (of Manchester), Richard Pilling (of South Lancashire) and other Chartists towards such questions will also be examined. In undertaking this exercise I am principally concerned to determine whether the views expressed by these selected Chartists conformed to the picture of Chartist ideas depicted by Stedman Jones. ${ }^{21}$ This question assumes added significance in consideration of the fact that McDouall, Pilling and Leach were prominent Chartists in that geographical area where the capitalist mode of production was most advanced. It was surely in the factory districts of Lancashire that Stedman Jones's political characterisation of Chartism would encounter its most severe test from the attempted determinations of the relatively new mode of production. Did the traditional language of political exclusion prevail (albeit in a stretched form), or did a more classbased ideology develop?

Whilst primarily concerned with the factory districts, I do, nevertheless, endeavour to go beyond a purely local or regional perspective. It will be

21 For Chartism in the cotton districts see R. Sykes, "Early Chartism and Trade Unionism in South-East Lancashire", in: The Chartist Experience; J. Foster, Class Struggle and the Industrial Revolution (London, 1974); N. Kirk, The Growth of Working Class Reformism in Mid-Victorian England (London, 1985), ch. 2. 
appreciated that O'Connor, Jones, Leach and McDouall were central figures in national Chartism and addressed a constituency far beyond Lancashire. And, despite their differences, it is suggested that these Chartist leaders did articulate shared anti-capitalist and class-based ideas which struck a sympathetic chord among many workers, especially those adversely affected by the proliferation of capitalist structures and practices. ${ }^{22}$ For it will be appreciated that the process of capitalist transformation (the maximisation of profit and full-blown commodity production upon the basis of wage labour) had advanced not only into the factory, but also into the "moral order" of petty commodity production in the household and workshop of town and countryside, and in the 1830's and 1840's constituted a powerful unifying force among seemingly diverse groups of workers. ${ }^{23}$ In order to illustrate these points, and to provide a comparative yardstick to Lancashire, I will examine the political economy of workers and Chartists in two of the main centres of "artisan" production, London and Birmingham.

Prior to that examination, I must, however, make brief reference to the fact that Stedman Jones's characterisation of pre-Chartist radicalism is by no means beyond contention. Indeed, an important recent study of the "Smithian socialists" 24 and the political economy of the working-class and co-operative press of the 1820 's and early 1830 's, Noel Thompson's The People's Science (1984), presents a forceful and (to my mind) convincing case in favour of the emergence and growth of popular economic explanations of poverty and exploitation in the pre-Chartist years. ${ }^{25}$ Given its relevant thesis and its curious lack of acknowledgement by the reviewers of Stedman Jones's essays, we must pause to consider Thompson's book.

Thompson and Stedman Jones do share two areas of agreement: the Smithian socialists (Bray, Gray, Thompson and Hodgskin) and im-

22 The primary aim of this article is to document the existence of anti-capitalist ideas within Chartism rather than to assess the relative weight of such ideas within Chartist ideology as a whole. As suggested to me by John Walton and Steve Jones, questions concerning the typicality of such ideas merit further investigation. This exercise is, however, largely beyond the scope of the present article.

23 For the process of combined and uneven capitalist development in nineteenth-century Britain see R. Samuel, "Workshop of the World: Steam Power and Hand Technology in mid-Victorian Britain", in: History Workshop, No 3 (1977), esp. pp. 7-13, 45-60.

24 N. W. Thompson, The People's Science: The Popular Political Economy of Exploitation and Crisis 1816-34 (Cambridge, 1984). Thompson suggests that Gray, Bray, Thompson and Hodgskin employed a notion of labour exploitation which owed far more to the thinking of Smith than that of Ricardo (pp. 86-90, 106).

${ }_{25}$ Thompson has written, unpublished correspondence, November 1985, that " $R e$ thinking Chartism' runs contrary at almost every point to the central thesis of The People's Science." 
portant sections of the 1820 's and early-1830's working-class press located economic exploitation primarily in the realm of exchange rather than in production; and such radicals were accordingly united in the belief that the way forward lay in "the rationalisation of exchange rather than any direct appropriation of the means of production". ${ }^{26}$ Beyond these points of agreement there arise, however, fundamental disagreements.

For example, in contrast to Stedman Jones, Thompson does not interpret the radicals' reluctance to mount a direct offensive against the forces of capital and their emphasis upon exploitation within exchange as signifying either a defence of profit per se or a celebration of the harmonious interests of "productive" workers and capitalists. Thompson shows that neither the Smithian socialists nor writers in the radical press ignored the inequalities rooted in the capitalist system between those who owned the means of production and those who sold their labour power; both saw changes in the system of ownership and the balance of power as necessary to the attainment of fairness and equality in exchange. ${ }^{27}$ Furthermore, claims Thompson, the Smithian socialists and many radicals viewed relations between labour and capital as necessarily antagonistic within a system of profit maximisation ("buying cheap and selling dear"), and, unlike Owen, did not hesitate "to condemn explicitly those social classes and groupings which they considered to be the instigators and beneficiaries of labour exploitation". And both the rent of the landowner and the profit of the capitalist were denounced as socially contrived and unjust deductions from the worker's "natural" right to the full value of the product. Whilst the specific labour of the workshop master was believed to be deserving of financial reward, the profit of the "capitalist" employer was, according to Thompson, seen as the ill-gotten gain of exploitation. ${ }^{28}$

It is Thompson's central conclusion that, unlike Owen, the Smithian socialists did offer "a clearly articulated theory of labour exploitation", according to which there occurred "a systematic process of value abstraction from the labouring classes and the beneficiary was the capitalist". ${ }^{29}$ Exploitation was therefore seen to be intrinsic to the capitalist mode of production and not ultimately attributable to political causes. The ideas of the Smithan socialists marked, in Thompson's opinion, a qualitative advance within the field of popular radicalism upon the beliefs which at-

${ }_{26}$ Thompson, The People's Science, op. cit., pp. 87-88, 96-102, 110.

27 Ibid., pp. 96, 145.

28 Ibid., pp. 108-09.

29 Ibid. For the relationship of Owen and Owenism to the political radicalism see G. Claeys, "Language, Class and Historical Consciousness in Nineteenth Century Britain", in: Economy and Society, XIV (1985), esp. pp. 246-56. 
tributed poverty and exploitation to factors exogenous to the economic system. ${ }^{30}$ Capitalists (in their roles as middlemen and master manufacturers) had come to replace placemen and sinecurists as the main oppressors of the workers, and the key social division lay "not between those in and those excluded from the political process, but those who possessed the economic power residing in the ownership of capital and land and those who entered the market with only their labour to sell". ${ }^{31}$

Thompson notes that the political economy of the Smithian socialists did not hold undisputed sway owithin popular radicalism. The traditional explanations of poverty offered by Cobbett and others, and highlighted in Stedman Jones's essays, did not suddenly disappear; and the ideas of Owen were, at various points, at odds with those of the Smithian socialists. ${ }^{32}$ Nevertheless, Thompson does cite solid evidence to support his claims that the economic theories offered by the Smithian socialists and Owen did constitute a new mode of discourse which gained greatly in popularity during the late 1820 's and early 1830 's, increasingly at the expense of noneconomic explanations. ${ }^{33}$

Thompson's book appeared in 1984, a year later than "Rethinking Chartism". It would, therefore, be totally unfair to have expected Stedman Jones to anticipate Thompson's every criticism. It is nevertheless curious, given the context in which Stedman Jones wrote his essays, especially the existence of a strong body of thought in favour of the increasingly class character of early 1830 's popular radicalism, ${ }^{34}$ that Stedman Jones simply assumed rather than established the uniformly political and non-classbased character of pre-Chartist radicalism. Certainly, no such ready assumption can easily withstand the findings of Noel Thompson's book.

\section{Chartism and the language of class}

From the mid 1830's onwards popular support for socialist political economy declined. Indeed, it is Noel Thompson's contention that after 1834 there occurred "not just a growing disenchantment with economic theorising and economic discussion but rather the degeneration and disintegration of anticapitalist and socialist political economy as such". ${ }^{35}$ I wish to make the somewhat different claim that, whilst socialist ideas had little influence in

30 Thompson, The People's Science, p. 110.

31 Id., unpublished correspondence.

32 Id., The People's Science, pp. 76-81, 148.

33 Ibid., pp. 148-50, 219-28.

34 See, for example, Thompson, The Making, p. 782.

35 Thompson, The People's Science, pp. 221-22. 
pre-1850's Chartism, nevertheless radical and, in some cases, de facto anticapitalist economic explanations of exploitation and misery did exert considerable influence within Chartism. It is to a consideration of this "other" language of Chartism, as expressed especially in the writings and speeches of McDouall, Leach, O'Connor, Pilling and Ernest Jones, that we must now turn.

In his Chartist and Republican Journal of 1841, Peter Murray McDouall provided a classic illustration of the growing importance of the "economic" in popular radicalism. McDouall, a surgeon resident in Ramsbottom, was an active and popular figure in both Lancashire and national Chartism. A delegate to the Chartist Convention of 1839 for the Chartist stronghold of Ashton-under-Lyne, McDouall was held in special esteem by the factory operatives of South Lancashire. ${ }^{36}$ In July 1841 he traced the economic, social and political roots of labour's failure to receive the full fruits of its industry. He wrote:

The reasons why labour is defrauded of its just wage, are first owing to the division of the great productive millions, and secondly to the combined power of the few masters who have the benefit of a limited number to co-operate, and an unlimited capital to support them in their monopoly. The great distribution of the labouring classes, and their division into so many crafts, and their subdivision under so many small masters render their subjection easy, and their submission certain. It is true there are trades' unions to protect wages; but [. . . ] what power can they possess, when trade is depressed? little or none against the combined power and capital of the master. [ . . .] They are excellent expedients, but unless they are supported by political power, they never can reach the root of the evils complained of. Why? because the masters individually have a great influence over them in a SOCIAL SENSE; and collectively, they have an overwhelming power over them in a POLITICAL SENSE. By this double acting engine, the masters regulate the wages of the workman according to pleasure [. . . ${ }^{37}$

As revealed in the above quotation, McDouall thus viewed the receipt of a "fair" wage as being dependent upon the enactment of the Charter. Along with other Chartists, and Marx and Engels, McDouall believed the power of trade unionism to be limited, and the real key to "secure and permanent remedy" for the workers' ills to reside in the achievement of the suffrage. ${ }^{38}$ It was in this sense that Chartists such as McDouall subscribed to the

36 R. Challinor, "Peter Murray McDouall and 'Physical Force Chartism", in: International Socialism, Second Series, No 12 (1981); Mick Jenkins, The General Strike of 1842 (London, 1980), pp. 36, 39, 161, 163-64.

${ }_{37}$ Mc. Douall's Chartist and Republican Journal (hereafter Mc. Douall's Journal), 31 July 1841 .

38 Ibid. 
primary role of political action. Simultaneously, however, McDouall and many other Chartists did view and explain the misery and exploitation of the working class in economic and social as well as political terms - hence the reference in the quotation cited above to the "double acting engine" of employer power and oppression. Thus, for McDouall and likeminded thinkers, whilst political action constituted the key to the full emancipation of labour, nevertheless legislation confirmed and buttressed rather than created economic exploitation. ${ }^{39}$

\section{Evils of capitalist production: The factory, 1}

In his Chartist and Republican Journal McDouall located the roots of exploitation not in the abuses of the system, in the "unfair" exactions and oppressions of individual capitalist "bad apples", but in the very growth of the capitalist mode of production during the late eighteenth and early nineteenth centuries. This exploitation was demonstrated most clearly in the factory system, the most complete form of the capitalist mode of production. What emerged from McDouall's investigations into the factory system was a production- and class-based theory of exploitation of a nonMarxist kind (at least being more conditional and specific than the necessary and universal theory expressed in Capital); a forceful and penetrating critique of capitalist social relations of production (which did anticipate Capital ${ }^{40}$ ); a somewhat idyllic portrayal of the "moral economy" of petty commodity, especially household, production; the embracement of changes in and alternatives to the existing factory mode of production, which included "backward-" and "forward-looking" elements; and an appeal to workers to adopt both industrial and political forms of action (albeit with primacy afforded to the latter) to overcome capitalist exploitation. And in both his diagnosis of and prescription for working-class ills,

39 Hence McDouall wrote, ibid. (italics added); "The trades can never have protection until they have political power. Because the masters have first the will to reduce wages, and they have secondly, the power to enforce a reduction. They make the workman first poor, and then they make him submissive. The exaction of the masters come [sic] first. That might be borne, had it been the only plucking to which workmen are subjected. It is, however, so contrived that after the master has concluded, the government begins their [sic] tything." The remainder of the article is devoted to criticism of the excessive burden of indirect taxation shouldered by workers.

40 Especially in its "moral" critique of reification and the loss of human concerns and values under a system obsessed with profit maximisation, competition and individualism. See K. Marx, Capital, I (London, 1970), pp. 71-83, 577-95, 645. For Marx's notions of alienation and commodity fetishism see also id., Selected Writings in Sociology and Social Philosophy, ed. by T. B. Bottomore and M. Rubel (London, 1956), pp. 167-77. 
McDouall was offering opinions which were in accord with those of a great number of Chartists, exploitation increasingly being seen in economic terms, but its abolition ultimately dependent upon political means.

Illustrations of the points made in the previous paragraph abound in $M c$. Douall's Chartist and Republican Journal. "I come to show you the system which has spread such ruinous changes around us", wrote McDouall in an early issue, "which has left the cottage mouldering on the hill, and driven destitution and vice into the lovely valley, which has extended its wings like the spirit of desolation over a happy people, and which towers on the plain of a people's history like the pillar of Lot". ${ }^{41}$ The system was, of course, the factory system, "one of our most splendid systems of oppression". McDouall sought his information not from the cotton masters, but from their operatives.

I pass by the golden chariot of the noble, the proud mansion of the merchant, the perishable tinsel of the cotton lord. I forsake the surface and floating toys which glitter on the stream of society, and penetrating to the cottage of the labourer, I sit down to investigate; there I collect my information, there only can my reason grasp and examine, and comprehend the REAL GREATNESS OF MY COUNTRY, AND THE REAL ROBBERIES OF THE FACTORY SYSTEM. I sit down with the poor man at his table, I mingle with the people at their firesides, I converse with the labourer at his work, and by these, and from these, I am now about to demonstrate to you the existence of most overwhelming evils at the basis of this, our so-called national prosperity;- evils, which if allowed to eat like a cancer into the vitals of our social intercourse, will destroy the nobler qualities of the human mind, arrest the march of man's ingenuity, and sacrifice this mighty nation to the worst of passions, and the basest of men.

"If I can prove to you", continued McDouall,

that all the magnificence, grandeur, and riches of the Factory System are counterbalanced by social evils of the greatest magnitude, and of the most solemn importance, then, I am not only performing a duty to my country, [. . ] but $I$ have also a right to arrest your attention and claim the best exercise of your judgment. ${ }^{42}$

McDouall's ultimate purpose was to raise

such a storm of opinion, as will rise above the tongue of wealth and the roar of machinery, which shall penetrate to the tables of the richest cotton despot, and liberate the suffering white slaves of my country from the chains of avaricious tyranny. ${ }^{43}$

41 Mc. Douall's Journal, 17 April 1841. Italics added.

42 Ibid., 3 April.

43 Ibid. 
McDouall was not alone in his indictment of the factory system. Richard Pilling, former handloom weaver who had been compelled by economic necessity to take up work as a powerloom weaver in Stockport, and an important figure in South Lancashire Chartism and trade unionism, ${ }^{44}$ was "not long in the factory" until he perceived "the evil workings of the accursed system $-[\ldots]$ a system, which, above all systems, will bring this country to ruin if it is not altered". ${ }^{45}$ In his Stubborn Facts from the Factories by a Manchester Operative (1844) James Leach, a leading light in both Manchester and national Chartism, ${ }^{46}$ condemned "the injustice and cruelty of the present manufacturing system." "We can see", wrote Leach, "nothing in the increase of factories, and the further extension of the factory system, but increasing slavery, destitution, and immorality amongst the many, and increasing luxury and extravagance for the few. ${ }^{, 47} \mathrm{O}$ Connor was equally outraged and hostile.

I have seen so much of this system; I have seen so much of the brutality of the purse-proud liberal masters, so much of the suffering of their slaves, both old and young, that I would cheerfully venture my life to-morrow to put an end to the damnable system, a system which if not stopped, will snap every tie by which society should be bound. ${ }^{48}$

And for Ernest Jones the factory system was a prime example of the "social wrong" which had fallen upon the country. ${ }^{49}$

It was as an expression of the growing capitalist mode of production and capitalist social relationships that the factory system met with such fierce Chartist criticism. For, in the eyes of the Chartists cited above, the growth of industrial capitalism in early- and mid-nineteenth-century Britain signified, for the majority of workers, not the freedom, independence and equality in the market-place so beloved of orthodox political economy, but "wage-slavery", dependence, structured inequality between worker and employer, and general misery.

McDouall pointedly entitled his articles on the factory system "The White Slaves of Great Britain". He maintained that the growth of factory textile production and the concentration of ownership into the hands of the

44 For Pilling see Jenkins, The General Strike of 1842 , op. cit., ch. 4.

45 The Trial of Feargus O'Connor, Esq., and Fifty-eight Others (London, 1843), p. 249.

46 For Leach see Sykes, "Early Chartism and Trade Unionism", loc. cit., pp. 171-72; Jenkins, The General Strike of 1842, pp. 53, 137-38, 227-28.

47 Stubborn Facts from the Factories, by a Manchester Operative [J. Leach] (London, 1844), pp. 3, 50.

48 The Trial of Feargus O'Connor, op. cit., p. viii.

49 J. Saville, Ernest Jones: Chartist. Selections from the Writings and Speeches of Ernest Jones (London, 1952), pp. 149-50. 
capitalists had proved ruinous to the handloom weaver and the domestic system of textile production. "What Has the Factory System Destroyed?", enquired McDouall; the independence, family economy, control over the pace and nature of work, and contentedness of the well-rewarded domestic worker, came the loud and instant reply. "Regarding the condition of the country previous to the introduction of the Factory System", wrote McDouall,

We find the hand-loom weavers, scattered over a great extent of [the] country, which is still marked by those old fashioned, but commodious houses of former times, with the broad-seated hearthstones, and the ever opened porch for the passing traveller. [ . ...

There he sat at his rattling loom, assisted by all of his family who could work; there the grown up child worked with the parent, and the mother left her other duties to taste recreation beside her husband. There you would find all the household manufacturers busily engaged together; there, too, the song and the laugh rose cheerily, and rung in chorus with the restless shuttle. Had you entered that dwelling you would have found the weaver at his light hearted easy task, the wife smiling amidst plenty. They were free, hospitable, and intelligent [. . .].

When the spring approached, and decked the fields with its splendid covering; when the summer ripened, and the autumn cast its blushing fruits in abundance at the feet of the farmer; then you heard the loom no more; the house was deserted, and the sickle and the scythe found a healthy employment for the weaver's family. [. . .]

This is no illusion of the fancy, this is no dream of the imagination; this is the truth, the whole truth, and nothing but the truth; this was the hand-loom weaver's condition in the olden times of our fathers. ${ }^{50}$

And, again with reference to the handloom weaver,

His labour was rewarded because he sold his own labour in the market for the highest price [.. .].

No oppressor could live amongst workmen, who consulted their own inclinations when to work, and when to give over. No tyrant could live in the cottage of a free labourer, who was well paid for the work of his hands, whose hearth was warm and hospitable.

Labour had its reward, and labour performed its duty. Intelligence, employment, and plenty combined to make a people great [ . . . ] combined to render England the pride and glory of her children [. . . ]. This period was when labour was protected, rewarded, and acknowledged as the basis of our social edifice; and this source of congratulation to us, this cause of the greatness of the empire, this foundation of our institutions, [ . . ] I have to prove to you have been swept away, overthrown, and dissipated by the spread of a great iniquity, and the establishment of a mighty curse, that of the 
Factory System. ${ }^{51}$

The factory system had encroached upon the Pennine hills and valleys with disastrous consequences.

The noisy prison houses of labour grew on the hill side, and in the valley; gas shone in the magnificent bastiles; bells rung to number the hours of labour; the very fish forsook the polluted streams, and the haunts of men encroached on the wild fastnesses of the land [. . .].

The palace and the factory, the carriage and the loom sprung up in company. The hand-loom weaver laid aside his necessaries; he now appeared in rags and in want [. . . ]. With him departed the small trader, the small dealer in the markets, the man who was satisfied with little profits and honest ones; with him perished the cheerful fireside of the cottage, the glorious independence of a well paid workman, the glorious freedom of a labourer who worked when he pleased, and as long as he choosed [sic]; with him perished the most noble, the most independent, and the most honest specimen of British labour; and, in the place of the hand-loom weaver arose a new order of things. ${ }^{52}$

In place of the handloom weaver appeared not the free, independent and equal worker of capitalist mythology, but the "wage-slave". Divorced from ownership of the means of production, totally reliant for an income upon the sale of his or her labour, lacking due protection and full reward for that labour, bereft of the resources available to capital, subjected to bouts of unemployment, insecurity and misery, dependent upon the capitalist for work, and lacking control over the pace, duration and time of work, the factory operative fully epitomised the indignities, exploitation, and inequalities endured by the worker under capitalism. McDouall pointed to the specific example of the spinner to illustrate his general point.

The cruelty of free labour is thus easily shown in the instance of the spinner. He is a free man: he comes to the capitalist, and says, buy my labour; he sells it, and binds himself to the rules and to the mill of the capitalist. What is this but slavery? where the body is more effecttually [sic] bound than if he were a real slave, because his consent is given as a free man. He can leave, you say leave what? the mill - to go only to another master, and do the very same labour for the same prices. He is free to change the place of torture. [. . . ]

Does [sic] his wages secure him enough to eat, to clothe him, and to provide for old age? They do not. Then he is worse than the slave even in regard to food. But he is worse in another sense. The free man commits suicide over the grave, and the slave is protected from that.

Why is this the case? because labour is not paid for its worth - because labour is sold lower than the labour of the slave, and it is permitted, because

51 Ibid., 10 April. Italics added.

52 Ibid., 17 April. 
the labour of the free man belongs to himself and not to the master, and because the master will not preserve anything but his own interest, or pursue anything else as long as he can get the raw material of human muscle as plentiful and as cheap as he does his cotton. The master has no interest in the labour of the spinner, except it be to get as much of it as he can at the least price.

Therefore in every sense of the case in regard to labour, to the length of it, to the payment of it, and to the freedom of it. The [sic] factory slave is in a worse condition than the condemned criminal, and he is less comfortable than the real slave..$^{53}$

Elsewhere, McDouall noted that the freedom of the spinner to change his employer was "worth nothing if he cannot have the privilege of working when he pleases and gaining a sufficiency, and live by his labour". "To chain your body to the bloody footstool of the capitalist", he continued, "to say then that the mind is free, that you are a free labourer, is utter delusion." McDouall concluded:

And if I were to have a choice between the two systems of slavery, that where I got all the physical benefits for mental ones, or that where I got a few imaginary ones and no bodily protection, I would not hesitate a moment which to choose; I would rather be the slave of the West Indies and possess all the physical benefits of real slavery, than be the white factory slave of England, and possess all the hardships of an unreal freedom. ${ }^{54}$

It is worth noting at this point that, whatever the historical deficiencies and inaccuracies in McDouall's portrayals of the domestic system, the factory system and chattel slavery ${ }^{55}$ nothing should be allowed to detract from his superb evocation of a profound sense of lost rights, of greatly intensified exploitation and of the disappearance of a whole way of life attendant upon the growth of factory- and the decline of cottage-textile production. Any positivistic attempt to relegate such feelings of loss to the realms of irrational myth, as having little or no foundation in "objective reality", ${ }^{56}$ should take urgent heed of Edward Thompson's warning against

53 Ibid., 10 July. The similarity between McDouall's and Marx's condemnations of the largely hollow character of the worker's "freedoms" under nineteenth-century capitalism will be readily observed. For Marx, see Capital, I, op. cit., pp. 176, 356.

s4 Mc. Douall's Journal, 3 July.

55 It could, for example, be argued that McDouall presented an idealised picture of the situation of the worker under petty commodity production, especially in relation to the eighteenth-century handloom weaver. But, in this context, see the cautionary note struck by Edward Thompson in ch. 9 ("The Weavers", esp. pp. 297-98) of The Making.

${ }_{56}$ See, for example, the unsatisfactory attempt by $\mathrm{N}$. McCord, "Adding a Touch of Class", in: History, LXX (1985), to draw a distinction between "belief" and "reality". What such a positivistic approach ignores or, at best, underplays is the role of consciousness as an integral part of "reality". See on this latter point R. Williams, Marxism and 
"the enormous condescension of posterity". As Thompson vividly demonstrated in The Making of the English Working Class, a shared sense of loss and displacement constituted a vital ingredient in early-nineteenth-century popular radicalism. The beliefs of handloom weavers, stockingers and other depressed occupational groups were "valid in terms of their own experience", and productive of widespread and passionate antagonism towards their rulers and employers. ${ }^{57}$ And as McDouall's writings forcibly demonstrate, by the Chartist period the springs of that antagonism were very much economic as well as political.

McDouall's condemnation of "wage-slavery" was, of course, shared by many other Chartists. To give but two examples. In the eyes of O'Connor, the factory system was equated with a lack of ownership, independence and economic well-being and security for the "serf" or factory "slave". In 1843 O'Connor contrasted the pleasures of a small farm system with the pain of the factory system.

Upon a farm a man can expend his own labour for his own advantage; he works like a free husbandman instead of as a serf; he works at wholesome labour; he works for himself, surrounded by his family [. . . ]. From the sweat of his brow he can bring up and educate his family without the dread of becoming a parish pauper, if he is weary he may rest without the dread of the overseer's knout falling upon his shoulders [. . . ]. He dreads not the sound of the factory bell, he is not haunted during the day with the galling and heartsickening reflection that he is compelled to wander in idleness from beer house to beer house until the time shall arrive when he will be called upon to attend at the living tomb of his infant daughter, and thence to convey her wasted and exhausted little frame to some loathsome underground cellar, wherein she breathes her last; her place being supplied by another infant slave, none to mourn her loss but the slave who begat her, or the slave that bore her: she was but a simple cog taken from one of the little wheels of free trade; she never had been anything in society, and, had she lived, she never would be. ${ }^{58}$

Such was the force of O'Connor's outrage and passion. And such feelings and beliefs did strike an extremely sympathetic chord among many of the factory operatives of Lancashire and Cheshire: they were expressive of a social view which was both rational and real to its holders.

Ernest Jones firmly attributed the ills of the working class to the concentration of ownership in the hands of the capitalist and aristocratic few. "What is social right?", asked Jones in the People's Paper in May 1852.

58 The Trial of Feargus O'Connor, p. viii. 
"We can best reply", he said, "by first depicting what society is at present social wrong."

A few landlords monopolise the soil and the minerals it harbours - the fish in its rivers, the game in its woods, and the very fowls in the air above.

A few money-lords monopolise the money-capital, the machinery, the powers of production, and the channels of distribution - they control credit, and they regulate exchange.

Spread at their feet lie the swarming myriads of man - having life, brain, thought, and labour-strength and with no other property on earth - but even that property is made a thing of no price, in the over-glutted labour-market of the mammonite.

These masses seek to apply the brain and labour-capital God has given them. They would dig the soil - but they have no soil to dig - the landlords hold it. They would work machinery - but they have no machinery to work the moneylords own it. They are therefore reduced to the position: they must ask another man: "May we work?" But that other says: "Yes, as long as it suits my convenience or conduces to my profit - and not one hour longer." Then comes the bargaining, the making of terms, the paying of wages. But land-and money-lords have it in their power to make what terms they like because, holding land and machinery - they hold exclusive possessions of the means of work. One thing only they fear - that labour should grow scarce. But the monopoly of land and the increase of machinery gives them the power of keeping labour plentiful - and so they have hungry swarms in streets and lanes, competing with each other for employment. They must work, if they mean to live; and therefore the capitalist can dictate starvation terms - for if one man won't toil for him another will - and he may reduce wages to the hairbreadth balance between life and death; he may tread out the moral dignity; he may stifle the manly independence, he may turn his factory into a seraglio, his land into a serf-trodden prairie, and all because he holds exclusive possession of the means of work. This is social wrong, in its fundamental aspect. ${ }^{59}$

\section{Evils of capitalist production: The factory, 2}

The tyrannical powers conferred upon the capitalist by means of ownership of the means of production were reinforced by a conscious desire to totally subordinate labour to the control of capital at the place of work - to tolerate no opposition, to stamp out any manifestation of worker independence, and to render the worker totally submissive to the employer. This, at least, was the reality perceived by McDouall, O'Connor and a host of workers responsive to calls for radical trade-union and political action. Fines for a wide variety of "offences" (late arrival at work, leaving work without notice and many other transgressions against the "rules of the mill"), fierce

59 Saville, Ernest Jones, op. cit., pp. 149-50. 
opposition to trade unions and the blacklisting of trade-union activists, the persecution of workers holding political views contrary to those of the owner, the introduction of cheap labour and machinery, the sexual harassment of women workers, and, of course, the "sack" were examples of the devices commonly used by capital and its agents to ensure mastery over the workers. ${ }^{60}$

As a result of his involvement in wage struggles in South Lancashire, Richard Pilling found that "the masters combined all as one man against me, and neither me nor my children could get a day's employment." ${ }^{11}$ And when a "gentleman" in Ashton was asked to provide a bottle of wine for Pilling's sick eldest son, the reply came: "Oh, he is a chartist, he must have none." Pilling's son died soon afterwards. ${ }^{62}$ A leading figure in the strike movement of 1842 (which he saw as an economic struggle against economic oppression ${ }^{63}$ ), Pilling was committed for trial at Lancaster. In his defence at Lancaster Pilling declared: "the masters conspired to kill me, and I combined to keep myself alive." ${ }_{64}$ McDouall saw in the fining system further evidence of the degradation of "free" labour under the factory system.

Should the weaver be found out of the area, he is fined, should he be found sitting down, he is fined, should he be found asleep, he is fined, should he be seen talking, heard shouting, or be caught reading, he is fined, in short, should the human being be found in any other position than that of rigid attention, to the task before him he is fined, the worker must be as constant in application, and as regular in movement and attention, as the metal itself. The worker must identify himself with the machine, and become a portion of the cast iron itself [ . . ]. No tyrant of a schoolmaster was ever more strict and severe than the factory master, and no system could be better adopted to break the spirit and degrade the independence of the human race, whether in a school or a mill. ${ }^{65}$

According to O'Connor, the free-trade employers preached freedom and independence, but practised slavery and dependence.

Have they not, as masters and as magistrates, followed up, persecuted, tortured, and, in many instances banished from their homes, every in-

60 For examples of employer "tyranny" see H. I. Dutton and J. E. King, "The Limits of Paternalism: The Cotton Tyrants of North Lancashire, 1836-54", in: Social History, VII (1982), pp. 60, 64-69; Kirk, Working Class Reformism, op. cit., pp. 267-72.

61 The Trial of Feargus O'Connor, p. 249.

62 Ibid., p. 251.

63 "And I do say that if Mr. O'Connor has made it a chartist question, he has done wonders to make it extend through England, Ireland, and Scotland. But is was always a wage question, and ten hours bill with me." Ibid., pp. 254-55, italics added.

64 Ibid., p. 255.

65 Mc. Douall's Chartist Journal and Trades' Advocate, 28 August 1841. 
dividual who has taken an active part in exposing their dishonesty and their ignorance? Have they not established the system of excommunication, by conspiring together, to banish from their employment every man who has taken an active part against them? [. . .]

however loud the free-traders were in their professions, yet was cruelty and a resolution to subjugate labour to capital, made manifest in their every act $[\ldots]{ }^{66}$

For Leach the employers "wield a dominion and enforce a tyranny over the lives and the liberties of their fellowmen, such as no government could for a moment attempt to enforce upon a nation without the risk of a violent and terrible revolution. ${ }^{67}$ In sum, the beliefs of McDouall, Pilling, O'Connor and Leach add weight to the recent claim made by Dutton and King that instances of employer "tyranny" were both frequent and bitterly resented by the operatives of Lancashire during the second quarter of the nineteenth century. ${ }^{68}$

The capitalists' desire for total control over production was perceived as being intimately connected to their craving for unrestricted capital accumulation. The unceasing pursuit of profit and the elimination of oppositional forces were seen by our selected Chartists as features essential to the factory mode of production. Unfettered individualism and competition, the usurpation of human by monetary values and rank hypocrisy on the part of the capitalists were similarly regarded as characteristics of the capitalist system itself rather than of isolated "dishonourable" masters. In an early issue of his Chartist and Republican Journal McDouall asked whether the factory system had been introduced "for the benefit of a nation, for the physical exhultation [sic] of a whole people, for the happiness of the British people"? A resoundingly negative reply was given.

No. All these changes were effected to serve the purpose of the capitalist, to accumulate wealth for a few, to satisfy the ambition of a fraction of the human race, and enrich one man at the expense of suffering thousands. ${ }^{69}$

For McDouall, the capitalist was a self-interested, "heartless accumulator of gold", a slave to "avarice and ambition".

The factory masters were maddened with the prospect of gain; for all now that was wanting to accumulate gold, was the rapid production of goods. What cared they for nature, for life, for infant slaughter; gold, gold, the blood of the infant for gold, was their cry.

66 The Trial of Feargus O'Connor, pp. vi-vii.

67 Stubborn Facts, op. cit., p. 40.

68 Dutton and King, "The Limits of Paternalism", loc. cit.

69 Mc. Douall's Journal, 17 April 1841. 
They were mad, they were drunk with profit; and in the race they spared neither nature nor justice, and regarded neither God nor man. ${ }^{70}$

In short, capitalists themselves were (as Marx was later to suggest in Capital) prisoners of their narrowly utilitarian and cash-based economic system. In "The Factory Master's Portrait" McDouall detailed the allconsuming and de-humanising pursuit of profit by the factory master.

If you see an immense block of buildings, with a large spire [ . .], you will not look far before you find a palace on the hill side. There the tyrant resides. Look at him, and you see him in a loose robe in the mornings sauntering about his mill [...]. Examine him, and you will find that his whole knowledge extends to the revolution of wheels; and although possessed of immense wealth, he knows nothing except the process of making cotton cloth or the most cunning way to drive a bargain. Every action of his life is measured by a foot-rule, and every thing he does is regulated by pounds, shillings and pence. He is grossly ignorant on all other subjects, and will express as much surprise at the mention of any subject for discussion on religion or politics, as if he was only a machine for producing calico, or a patent ledger for calculating profit and loss. [. . . He lives for no other purpose than to calculate, and the only end of his existence is to gain. ${ }^{11}$

McDouall's picture of the capitalist as a wealthy, scheming philistine was shared by other Chartists. For O'Connor the Anti-Corn-Law League employers were motivated solely by considerations of self and factory, of "how that living tomb can be worked with cheap labour". ${ }^{72}$ And in Leach's view, the same League employers were concerned only to "amass princely fortunes without any regard whatever for the well-being of their ill-used and toil-worn slaves". ${ }^{73}$ This was hardly the language of shared interests between the producing classes.

The maximisation of profit was to be achieved by successful competition against other capitalists and by cutting costs, especially labour costs, to the bone. Chartists were bitterly critical of such practices. In Pilling's opinion capitalist competition inevitably meant insecurity and ruin for those not successful in the marketplace. ${ }^{74}$ For McDouall competition resulted in overproduction, falling prices and unemployment, and unemployment depressed demand and the overall level of economic activity. ${ }^{75}$ Ernest Jones was in fundamental disagreement with Charles Kingsley's belief that acute

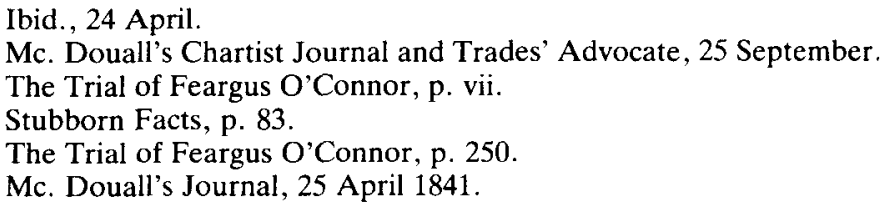


capitalist competition resulted in small profits and a consequent inability, despite honourable intentions to the contrary, to pay high wages. "I tell you and them", thundered Jones,

they have no right to murder me in order to live themselves. Who make the competition? THEY! What is it made for? FoR THEIR advantage. Then I say if they choose to fight each other they've no right to place the body of the working man between them, to receive the blows from both. Away with them! Away with them! The turn of the Barabbases is come - and the Christ of Humanity shall be triumphant at last. ${ }^{76}$

Cost cutting took a variety of objectionable forms. The employment of cheap female and child labour was widely condemned. O'Connor claimed that all master manufacturers were "alike engaged in the one common traffic of buying cheap and selling dear", a commonly held belief within Chartism. ${ }^{77} \mathrm{O}$ 'Connor further decried the disruption to family life and role expectancy consequent upon paid employment for women and unemployment for males.

Do they not work your wives and daughters to death, while they compel you to walk the streets in idleness? Have not your wives petitioned them over and over again that their husbands may be allowed to share their toil, and have they not indignantly refused? Is it not a notorious fact that the stern virtue of your wives and daughters is the only guarantee you have for their protection ${ }^{78}$

Leach maintained that capitalists deliberately preferred women workers, even when the latter were "heavily pregnant", "not because the women can perform the work better or turn off a greater quantity, but because they are considered to be more docile than men under the injustice that in some shape or form is daily practised upon them". ${ }^{79}$ The harassment of women at work (a more widespread practice than often realised ${ }^{80}$ ), overwork and driving, the employment of pauper apprentices and child labour in general were likewise opposed. ${ }^{81}$ In the Chartist scheme of things, women were to be rescued from the horrors of wage-slavery and be given the opportunity to return to the home. ${ }^{82}$

76 Saville, Ernest Jones, p. 149.

$\pi$ The Trial of Feargus O'Connor, p. viii.

78 Ibid., pp. vi-vii.

79 Stubborn Facts, p. 12.

80 See, for example, Mc. Douall's Journal, 14 August 1841; J. Lambertz, "Sexual Harassment in the Nineteenth Century English Cotton Industry", in: History Workshop, No 19 (1985).

${ }^{81}$ The Trial of Feargus O'Connor, pp. vi-vii, 252-53; Stubborn Facts, p. 12; Mc. Douall's Journal, 19 and 26 June, 31 July, 7 and 14 August 1841.

82 See, for example, Mc. Douall's Journal, 7 August; Thompson, The Chartists, p. 148. 
Technological change in general and the introduction of machinery in particular constituted further ways in which cost cutting could be facilitated. The Chartists under review were opposed neither to technological improvement nor mechanisation, but, rather, to their misuse under the capitalist imperative of profit maximisation. It was strongly believed that machinery had been employed not to lighten the burden of labour, to reduce hours and afford greater opportunities for leisure and domestic activities, but to increase unemployment and the size of the reserve army of labour, and so reduce wages and increase profits. Pilling, McDouall, Leach and scores of other Chartists argued in the above way. ${ }^{83}$ O'Connor directed particular criticism at the master manufacturers of the Anti-CornLaw League. The League, he declared, "is composed of the owners of machinery, and machinery is the great, the monster enemy of an unrepresented people." And "Since machinery and capital became represented in the House of Commons, the hostility between master and man has become greater and greater every year". ${ }^{84}$ Lack of protection for the worker and the capitalist's unrestrained pursuit of profit ensured the continuation of hostilities, and poverty, wretchedness and insecurity in the midst of plenty. ${ }^{85}$

Finally, it was claimed by McDouall and others that the organisation of production along the lines of profit maximisation ensured that human considerations and values had been displaced by those of the cash nexus. Workers had, in effect, to sell themselves to the capitalist; they had become factors of production, items of cost, objects. Relations within production had become depersonalised, and notions of the "just" price or wage associated with petty commodity production had been banished by the triumph of the "free" market, in which "laws" and "truths" were to be determined solely by the forces of supply and demand. As Edward Thompson has remarked, this was the new political economy anatomised by Marx in Capital. ${ }^{86}$ But what is impressive about McDouall and others is the extent to which they grasped and fought against the new, reified relations of industrial capitalism. Hence McDouall penetrated to the heart of the capitalist's hypocrisy.

The civilized mill-owner, the christian, the church-builder, and the religious curate reasons thus; this little devil of a piecer is not my property, but his labour is: what use is his body except it be for the work it will do. I will make him work as long and as much as I can, and if I kill him, why another will

83 Stubborn Facts, pp. 7ff., 26.

${ }_{84}$ The Trial of Feargus O'Connor, pp. vi-vii.

85 Ibid., pp. 279-81; Mc. Douall's Journal, 7 August.

s6 Thompson, The Making, p. 222. 
supply his place. The raw material is as easy to be got as my cattle. If this little white devil dies I can get another. The father of the child is the loser, not me. I can get the labour of another ${ }^{87}$

Chartism and other early- and mid-nineteenth-century working-class movements were concerned not only with hunger and poverty, but also with "moral" questions concerning the workers' pride, independence, and right to be treated as rational and creative human beings rather than as passive, dutiful machines. ${ }^{88}$ "The worker must identify himself with the machine, and become a portion of the cast iron itself", declared an outraged McDouall. A "simple cog taken from one of the little wheels of free trade", was the way in which O'Connor described an infant "wage-slave" ${ }^{89}$ The resurrection of human values, of mutuality and trust, freedom and independence were central to the alternative political economy of the Chartists.

- Such was the nature and. force of the critique of industrial capitalism, especially in its factory form, offered by McDouall and other Chartists. Given the deep sense of justified grievance and anger felt by workers in the cotton districts, it is hardly surprising that "physical force" Chartism and militant industrial action had such a mass appeal. The factory-owners had, as Stedman Jones himself concedes, come to be identified as the principal enemies of the "People". However, what Stedman Jones underplays is the extent to which hostility towards employers and their allies had become economic as well as political and social in character. Capitalist employers in general were perceived as being opposed to the political demands of the "People" and, with few exceptions, united in a structured and conscious attempt to exploit their workers within production. It is true that the economic critique offered by McDouall, O'Connor and others did not embrace revolutionary socialist goals, but it was, nevertheless, saturated by notions of class pride and class exploitation. To identify class-consciousness with revolutionary Marxian socialism, as is arguably the case with Stedman Jones, is to adopt an extremely narrow and "true" definition of class which fails to do justice to the extent of actually existing class-consciousness in the 1830 's and 1840's. We shall return to such matters in the concluding section. It should, however, be noted at this point that leading Chartists, most prominently O'Connor, did not adopt a position of indiscriminate opposition to all sections of the middle class. Shopkeepers, for example, were believed to share certain interests with their working-class customers, and were accordingly treated more sympathetically by the Chartists than those

89 Above, pp. 24, 26. 
engaged in antagonistic productive relations with workers. ${ }^{90}$ Economic criteria thus played an important part in Chartist calculations concerning potential allies.

\section{Evils of capitalist production: The workshop}

The provision of an adequate assessment of Chartism as a class movement requires that brief attention be paid to two further issues: the development of anti-capitalist ideas within centres of "artisan" production, and the general aims of Chartism.

Recent research has demonstrated that economic hostility to capitalists and their system was to be found not only in the factory districts, but also increasingly in London, Birmingham and other centres of workshop production. As capitalist structures and practices made rapid inroads into the sphere of petty commodity production during the first half of the nineteenth century, so many artisans and skilled workers adopted new and radical ways of re-creating the values of the moral social order. As Edward Thompson, Prothero and others have shown, widespread artisan support for Owenism, general unionism and Chartism was indicative of the heightened appeal of radicalism..$^{91}$ Simultaneously, conflict at the point of production escalated, and by the Chartist years artisans and skilled workers were attacking not only parasitical middlemen and exploitation within exchange, but also the growing influence and conscious exploitation practiced by capitalist employers within production..$^{92}$

David Goodway has, for example, demonstrated that the spread of capitalist structures into London's trades catering for the luxury market and the mushrooming of "dishonourable" capitalist practices (the beating down of wages and trade-union defences, sweating and the like) in those trades serving the mass market underpinned the capital's growing class conflict and Chartist strength during the 1840's. It is true that the typical unit of production in London at mid century continued to be "a tiny shop with either a master working alone or employing one, two, three or four men", but, according to Goodway, "Whatever the size of the average unit, workers in the Chartist period had no doubts that large (or larger)

90 J. Epstein, The Lion of Freedom: Feargus O'Connor and the Chartist Movement, 1832-1842 (London, 1982), pp. 273-74.

91 Thompson, The Making, ch. 8; I. J. Prothero, "London Chartism and the Trades", in: Economic History Review, Second Series, XXIV (1971).

92 See the view of Noel Thompson outlined above, pp. 14ff. For an emphasis upon the notion of exploitation within exchange rather than within production, see I. J. Prothero, Artisans and Politics in Early Nineteenth-Century London: John Gast and his Times (Folkestone, 1979), esp. p. 336. 
employers, engrossing a disproportionate share of the market, had risen and were continuing to emerge from the shoal of small masters nor that a capitalist system was remodelling productive relationships." 93 A London carpenter complained that the larger "capitalist" employers in the building trades "often treat you worse than the dogs that prowl the streets of the metropolis", and explained capitalist behaviour in terms of "a love of gain, that a few men may amass largely, while the mass of the men of the trade are reduced to a state of slavery, dependent on the caprice of these men for the food that sustains life". ${ }^{94}$ Similar complaints were widespread throughout London's trades. Goodway concludes that the accelerated pace of capitalist development in London during the second quarter of the century, the making of a metropolitan proletariat and the growth of slop production "moulded the working-class politics and trade unionism of the thirties and forties [. . .], forging a common consciousness of disparate groups of workers". 95 And part of this common consciousness was economic antagonism towards capitalist employers.

Similarly, Clive Behagg has argued that structural economic change in Birmingham placed great strains upon the notion of harmonious "productive classes" during the Chartist period. According to Behagg competitive production for a mass market altered the face of Birmingham's economy during the 1830's and 1840's.

Whilst the typical unit of production remained the small workshop held in master-artisan hands, the relationship between large- and small-scale units of production was changing. Factories emerged in most industries, increasing the degree of competition within trades generally [. . . . At the same time the small master found himself increasingly dependent upon the market and credit facilities of either the merchant, the factor or the large-scale manufacturer, a relationship which continually eroded his traditional independence. ${ }^{96}$

Faced by increased competition and lacking the advantages of economies of scale, the smaller employers attempted to compensate by increasing hours of labour and sweating. Worker complaints concerning degradation, proletarianisation and diminished opportunities for upward occupational mobility became widespread during the 1830 's. Many artisans became garret masters, and in a period of falling prices and intensified capitalist

93 D. Goodway, London Chartism 1838-1848 (Cambridge, 1982), pp. 6-7.

94 Ibid., p. 7.

95 Ibid., p. 9.

9 C. Behagg, "An Alliance with the Middle Class: the Birmingham Political Union and Early Chartism", in: The Chartist Experience, p. 69; cf. id., "Custom, Class and Change: The Trade Societies of Birmingham", in: Social History, IV (1979), pp. 458-63. 
competition wages generally were forced down and unemployment and underemployment rose. The upshot was a sharp escalation in strikes and other forms of economic conflict between labour and capital. As a member of Birmingham's Working Men's Memorial Committee observed in 1837,

When the masters found by these fluctuations in trade, their interests were being sacrificed and they could not maintain their prices they turned upon the men and reduced their wages in the hope of being able, by that means, to meet the competition and carry on. Had they, in place of doing so, taken their workman by the hand and gone to the government and represented their mutual distresses; and insisted upon relief [ . . ] they would [ . . . ] have obtained effectual redress, but in place of doing so the masters carried on the murderous system of competition; wages were reduced to the lowest scale of endurance; and general poverty, distrusts, dislikes and combinations were the consequences. ${ }^{97}$

Is was as a result of such developments that the notion of the "productive classes", so favoured by Attwood and his middle-class reformers in Birmingham, had become by the late 1830's "a fairly hackneyed formula which had to be constantly reiterated by Attwood precisely because the class unity it implied was increasingly at odds with work-place reality". ${ }^{98}$ And structural economic change and economic conflict, along with mounting differences in political perspective, accounted for the collapse of the social and political alliance represented by the Birmingham Political Union in 1839. Similar economic and political strains between Chartists and middleclass reformers manifested themselves in Sheffield, Leeds and other centres of workshop production. ${ }^{99}$

The changes within petty commodity production outlined above provide significant pointers to the nature of artisan political consciousness during the Chartist years. Of greatest importance was the fact that what had formerly been seen as uncharacteristic capitalist abuses of production-

97 Id., "An Alliance with the Middle Class", p. 72; cf. Prothero, Artisans and Politics, op. cit., pp. 224-25.

98 Behagg, "An Alliance with the Middle Class", p. 69.

99 It must, however, be remembered that the pace and extent of structural economic change and proletarianisation varied considerably both within and between trades. See, for example, F. K. Donnelly and J. L. Baxter, "Sheffield and the English Revolutionary Tradition, 1791-1820", in: International Review of Social History, XX (1975); J. L. Baxter, "Early Chartism and Labour Class Struggle: South Yorkshire 1837-1840", in: Essays in the Economic and Social History of South Yorkshire, ed. by S. Pollard and C. Holmes (Barnsley, 1976). In some centres of "artisan" production, where economic change did not threaten the position of a "labour aristocracy", middle- and working-class radicals tended to work together more easily. See, for example, G. Crossick, An Artisan Elite in Victorian Society: Kentish London 1840-1880 (London, 1978), ch. 10; R. Q. Gray, The Labour Aristocracy in Victorian Edinburgh (Oxford, 1976), pp. 155-64. 
"unfair" masters, "dishonourable" practices and the like - were by the 1830 's identified as constituting an "unnatural" and unwelcome system of production in itself, a system which, if not opposed and defeated, would come to dominate the whole world of workshop production to the detriment of the "honest" worker and (the fast disappearing) "honest" employer intent upon abiding by the rules of the "moral economy". In sum, experience demonstrated that a new capitalist system had arisen within the workshop, and that such a system had, as its distinguishing and general characteristics, poverty, insecurity, exploitation within production by avaricious employers intent upon profit maximisation and class conflict. ${ }^{100}$ In addition to political grievances, many artisans thus suffered from a catalogue of economic ills attendant upon the growth of capitalist production. And in identifying both the capitalist and the unrepresentative political system as enemies of the "People", Chartism was deeply expressive of the shared class perspective of seemingly disparate individuals and groups in the workshops and factories of Britain. This was the meaning of class. ${ }^{101}$

\section{Chartist aims}

And yet such an analysis must go further, to consider not only the grievances of Chartist artisans, factory operatives and others, but also their desired ends. For an influential strand within Chartist historiography is that which emphasises the essential fragility of class within the movement, the disagreements as to tactics and ultimate goals. O'Connor is set against Lovett, Jones against O'Connor, socialism against the Land Plan, artisans against factory operatives, and "moderates" against "extremists". ${ }^{102}$ How, given this article's emphasis upon the class character of the movement, can such diversity and division be explained? The tentative answer offered is that Chartism was underpinned by a common stock of general political, economic, social and cultural aspirations which found specific, practical expression in a variety of ways, ranging from the Land Plan, to the demand for "a fair day's wages for a fair day's work", to Ernest Jones's socialism. ${ }^{103}$

100 The claim is made here that Stedman Jones greatly underestimates the extent to which former "abuses" had, by the 1830's, expanded into a system of production, and that such a system was perceived by many Chartists as intent upon achieving a hegemonic position within the world of production as a whole. See RCh, pp. 116-17.

${ }_{101}$ Thompson, The Making, pp. 8-10; Thompson, The Early Chartists, op. cit., Introduction.

102 Thompson, The Chartists, pp. 2-5, 304-06; A. Briggs, "The Local Background of Chartism", in: Chartist Studies, ed. by id. (London, 1959).

${ }^{103}$ For example, the goals of individual and collective worker independence, which were central to Chartism, were to be achieved by such various (yet complementary rather than conflicting) means as trade unionism, political struggle, co-operation and the Land Plan. 
To offer such an answer is, of course, to endorse Asa Briggs's view of Chartism as an umbrella movement which was not committed to any single "ism". ${ }^{104}$ But it is also to go beyond such a viewpoint, to claim that the very variety of schemes adopted by the Chartists should not be allowed to obscure the shared general aspirations which unified the seemingly disparate groups and ideological tendencies within the movement.

To be more specific. In the eyes of large numbers of Chartists the attainment of the Six Points was seen as the means towards the creation of a social order which, whilst not socialist in character, would represent a radical departure from the status quo. The following features could be seen as the essentials of this alternative social vision: a far more open, democratic and egalitarian society based upon co-operative and human, rather than competitive and cash, values; freedom from monopolists and parasites, and the oppressive and tyrannical actions of capitalist employers and the State; the eradication of glaring inequalities of wealth, power and income; the provision of the material and other preconditions (due protection and reward for labour in the form of wages, hours, conditions of, and control over, work, ${ }^{105}$ controls over prices and profits, and greatly improved access to education and other forms of mental culture) essential to the ending of wage-slavery, and to the enjoyment of the benefits of a civilised existence befitting genuinely free and independent citizens; ${ }^{106}$ the termination of structured inequalities and antagonisms between employers and workers by means of checks upon the size of units of production, the ownership of such units either co-operatively or by small and "fair" masters, and enhanced opportunities for upward occupational and social mobility; ${ }^{107}$ and the humanisation of economic affairs by the organisation of production

104 Briggs, "The Local Background", loc. cit., pp. 2-3, 15; id., "National Bearings", ibid., p. 291.

105 Thus, McDouall: "Never, my friends, will the free labourer rise superior to the black slave, until he has the power in his own hands of shortening the hours of his labour: of securing better payment for his labour, and of possessing the real privilege of the free labourer, which are [sic] simply to be paid well for his labour, to possess the means of protecting it, and to have the free liberty of enjoying it", Mc. Douall's Journal, 10 July 1841. James Leach wanted "an alteration in the institutions of this country as will guarantee to labour that protection which it so imperatively demands", The Trial of Feargus O'Connor, p. 278. See also ibid. for the views of Pilling (pp. 249-51) and Christopher Doyle (pp. 268-70) on such matters. Demands for greater control over the pace, nature and duration of work and for workers to receive the full fruits of their labour were often made in the Chartist period. See, for example, Mc. Douall's Journal, 10 and 17 April, 10 July; Saville, Ernest Jones, p. 151.

106 See, for example, Mc. Douall's Journal, 10 July, 7 August.

107 Ibid., 17 A pril; Saville, Ernest Jones, p. 151; Thompson, The Chartists, p. 337. 
primarily for rational and useful purposes, rather than for mindless and unceasing profit maximisation. ${ }^{108}$

\section{Chartism as a class movement: An assessment}

If viewed from the Marxism of Capital or the class-based language of latenineteenth-century socialism, it is indeed the case, as observed by Stedman Jones, that the political economy of Chartism was deficient. The Chartists did not develop a theory of exploitation in production based upon the extraction of surplus value by employers from workers, and, whilst opposed to wage-slavery, did not seek to expropriate the expropriators, smash the State and establish a system of common ownership. Similarly, there is undoubtedly an element of truth in Stedman Jones's emphasis upon the customary nature of Chartism's goals. We have, for example, clearly seen the ways in which McDouall idealised the system of household production. And, as Edward Thompson has noted, backward-looking thought was certainly a part of artisan consciousness during the 1820's and 1830's. ${ }^{109}$

It is, however, from this point onwards that fundamental differences emerge. Curiously, and ironically, common appeals to historical context yield conflicting results. Thus, in opposition to Stedman Jones's characterisation of Chartism as essentially political, I have posited the growth of a movement saturated by class, possessing economic as well as political (and cultural) notions of class oppression and class conflict. McDouall and other Chartists did identify a cancerous capitalist system as the source of many of the workers' ills. And inscribed within this notion of system were the elements of underlying structural dynamic (ceaseless profit maximisation) and conscious agency (the desire of the capitalist to subjugate labour to capital's will). Now it is true that McDouall's notion of system does not satisfy the structuralist test of hidden and unchanging system or structure (McDouall was a great believer in the power of people, events and processes to modify, even change, systems), ${ }^{110}$ but it did nevertheless constitute an extremely powerful and popular economic theory of exploitation of a non-Marxist kind.

It may well be the case that it is Stedman Jones's employment of an "absolute" or "true" view of class which blinds him to the language of

108 Mc. Douall's Journal, 17 April; Saville, Ernest Jones, pp. 151-52; Thompson, The Making, p. 913.

109 Thompson, The Making, p. 12, ch. 8.

110 Herein lies an important key to mid-Victorian working-class reformism: the advances made by workers's organisations during the late 1840's and 1850's and the establishment of a foothold, however unstable, within the existing "system". I fully endorse Stedman Jones's views upon this development. See Kirk, Working Class Reformism, ch. 4. 
economic exploitation within Chartism. For at several points in his essays on Chartism he appears to equate class-consciousness with Marxist or revolutionary socialist consciousness. And in their "failure" to meet the required standard of Marxist consciousness, the Chartists are, in effect, deemed to have thought and acted in "non-class" ways. Thus the absence within Chartism of a Marxist theory of exploitation is falsely assumed to indicate the complete absence of economic explanations of poverty and exploitation within the movement and the primacy of a political explanation (LCh, pp. 15, 18-20). Stedman Jones may, of course, be directing his attacks against Foster's notion of "revolutionary consciousness" in 1840's Oldham, but this is not made explicit. And, in truth, I suspect that Stedman Jones's attacks are part and parcel of his general offensive against the "social" interpretation of Chartism (LCh, pp. 3-6).

The employment of a "true" definition of class leads to further problems and weaknesses. For example, Stedman Jones employs class in such a narrow, predetermined way as to exclude not only the Chartists, but also the vast majority of modern British workers from class membership and feeling. After all, relatively few workers have exhibited the pure consciousness to be found in the pages of the Communist Manifesto or twentieth-century manuals of Marxism-Leninism. Yet, depending upon the employment of different criteria, class continues to exert a major influence in the Western world, even within the heartlands of Thatcher and Reagan. Real people, of course, rarely conform to predetermined, clinical models. And in stating this obvious fact I feel downright embarrassed. For, in addition to Edward Thompson, it has been Stedman Jones, especially in his work on workingclass culture, ${ }^{111}$ who has most keenly alerted me to the pitfalls of preconceived views of class. Ironically, in his Chartist essays Stedman Jones is, despite his intentions to the contrary, himself lured into the very same trap of predetermination which, he informs us, has enshared the "social" interpreters of the movement.

There arises the additional but related problem concerning the nature of the correspondence between different levels of abstraction. I wish to suggest that Stedman Jones appears to have assumed far too easy a level of correspondence or "fit" between, on the one hand, the highly concrete and complex actually existing consciousness of the Chartists and, on the other hand, the highly abstract and deliberately oversimplified picture of proletarian consciousness portrayed by Marx and Engels in a propagandistic work such as the Communist Manifesto or in the more "theoretical"

111 Esp. his "Working-Class Culture and Working-Class Politics in London, 1870-1900", in Languages of Class. 
works of Capital and the Grundrisse. Now, whilst it is both necessary and fruitful to explore the relationships and tensions between the different levels of abstraction, it is surely improper to collapse the more abstract into the more concrete, the "ought" into the "is", on the simple grounds that we are not comparing like with like, the former being deliberately selective and purified, whilst the latter is more comprehensive and naturally complex. ${ }^{112}$ Stedman Jones does, however, tend to treat "is" in terms of "ought". As a consequence the actually existing consciousness of Chartist experience appears, almost inevitably, as a laggard in relation to the pure consciousness of the Communist Manifesto. The great irony is that, whilst emphasising the central importance of context, language and the avoidance of predetermined notions of Chartist consciousness, Stedman Jones seems, himself, to have judged Chartist language against a narrow and unsatisfactory "absolute" standard. And in his attention to one particular strand of language within Chartism, he has tended to underplay the significance of other kinds of language and the material experience which both shaped and was moulded by language. ${ }^{113}$

Once we dispense with the notion of "true" consciousness and agree with Edward Thompson's claims that "Class eventuates as men and women live their productive relations, and as they experience their determinate situations, within 'the ensemble of the social relations", and that "No actual class formation is any truer or more real than any other, and class defines itself as, in fact, it eventuates", ${ }^{114}$ then we can more fruitfully explore the nature of Chartist consciousness within its own historical context, within its own meanings and points of reference, and in relation to the judgments of contemporaries and historians - without expecting a perfect fit between "is" and "ought". And the claim made in this article is that class feeling, the growth of an "identity of [...] interests as between themselves, and as against other men", ${ }^{115}$ was the overriding fact of working-class life during Chartism. This was also the viewpoint expressed by Engels in The Condi-

112 For the Marxist method of abstraction see the very helpful article by Richard Johnson, "Reading for the Best Marx: History-Writing and Historical Abstraction", in: Making Histories, ed. by id. et al. (London, 1982).

113 Foster, "The Declassing of Language", loc. cit., pp. 40-41, 43, has made the important point that, in adopting a "non-referential conception of language", Stedman Jones ignores the meanings of words within specific historical contexts. "The crucial nexus of social practice, language and consciousness is simply ignored", writes Foster; the study of language is effectively divorced from an examination of social practice, and the upshot is a form of idealist reductionism.

${ }_{114}$ E. P. Thompson, "Eighteenth-Century English Society: Class struggle without class?", in: Social History, III (1978), p. 150.

115 Id., The Making, p. 9. 
tion of the Working Class in England. Engels saw in the development of trade unionism and Chartism evidence of class-consciousness, a consciousness which, whilst not socialist or Marxist in character, did nevertheless signify mounting opposition to laissez-faire capitalism and the bourgeoisie as well as solidarity on the part of different groups of workers. ${ }^{116}$ Engels wrote:

Chartism is of an essentially social nature, a class movement. The "Six Points" which for the Radical bourgeois are the beginning and end of the matter [ . . . ] are for the proletarian a mere means to further ends. "Political power our means, social happiness our end," is now the clearly formulated war-cry of the Chartists. [ . . ] There is no longer a mere politician among the Chartists, and even though their Socialism is very little developed, though their chief remedy for poverty has hitherto consisted in the land-allotment system, [ . . ] though their chief practical propositions are apparently of a reactionary nature, yet these very measures involve the alternative that they must either succumb to the power of competition once more [...], or they must themselves entirely overcome competition and abolish it. On the other hand, the present indefinite state of Chartism, the separation from the purely political party, involves that precisely the characteristic feature, its social aspect, will have to be further developed. The approach to Socialism cannot fall, especially when the next crisis directs the working-men by force of sheer want to social instead of political remedies. ${ }^{17}$

Engels's views are of interest to us in a number of ways. Firstly, they do reflect, as perceived by Stedman Jones, an economistic approach to the formation of consciousness. Secondly, there is the emphasis upon "stages" of consciousness, which are formulated in terms of linear and inevitable progression. Thirdly, and of most immediate relevance, is Engels's eschewal of an "absolute" view of class and his concern with context, experience and with actually existing worker consciousness, complete with its contradictions and ambiguities. In other words, Engels was alive to the complexities of concrete reality; class did not have to exist in the highly abstract (and deliberately oversimplified) form of the Communist Manifesto to qualify as class. There is of course the possibility, as claimed in "The Language of Chartism", that Engels was, ironically, mistaken ("falsely conscious"?) as to the true character of Chartism. But the suggestion offered here is otherwise. Engels certainly had the advantage of living and working in the manufacturing districts and of observing worker reactions to the factory system. And his views in The Condition of the Working Class in England were surely not superimposed upon totally 
unresponsive evidence, but represented more of an engagement between theory and concrete experience and observation. ${ }^{118}$

It is, furthermore, extremely difficult to see how the Chartists could have moved "in the direction of a class-based theory of exploitation of a social democratic or Marxist kind" when, at least in the years before 1848, Marx had not established the fundamentals of his theory of surplus value, and thus found the key to the riddle of exploitation under conditions of commodity production. ${ }^{119}$ And, as noted earlier, in their "moral" critique of capitalist relations of production the Chartists were anticipating the moral outrage expressed by Marx in the pages of Capital.

Brief reference must be made to four other issues. Firstly, whilst in part a customary movement, Chartism was also, indeed predominantly, forwardlooking. Indeed, defences of customary practices and values and the creation of new, radical and even revolutionary forms of activity and thought were interconnected parts of working-class experience. Despite Calhoun's claim to the contrary, artisans were not characterised by a static, wholly backward-looking consciousness. ${ }^{120}$ Change, contradiction and process were of the essence. As demonstrated by Edward Thompson and as clearly seen in McDouall's writings, a sense of lost rights could and did increasingly constitute a rich source of class-consciousness. ${ }^{121}$ The process of transformation of worker consciousness has been succinctly expressed by Hobsbawm.

Prothero has shown how artisans who began simply by trying to defend or re-establish the old "moral economy" could find themselves driven, under the pressure of the economic transformations of the early nineteenth cen-

118 E. J. Hobsbawm, "History and 'The Dark Satanic Mills"”, in Labouring Men (London, 1964).

119 The key lay, of course, in Marx's distinction between the concepts of labour and labour power. Marx's pamphlet Wage Labour and Capital was published under Engels's guidance in 1891, but originated in a series of articles by Marx in the Neue Rheinische Zeitung in April 1849. Engels explained that he was forced to correct it as it did not, in the original, distinguish between the concepts labour and labour power - hence no theory of surplus value. According, however, to Rosdolsky (quoting from Marx's Grundrisse) by 1848 "his theory of surplus-value, the cornerstone of his economic system, was established in its fundamentals", although due to interruptions to Marx's work the developed concept of surplus value would probably be dated to 1850-51. I am grateful for this information to a colleague, Keith Gibbard, in the Department of Economics, Manchester Polytechnic. See also D. McLellan, Karl Marx: His Life and Thought (London, 1973), pp. 296, 344-46.

120 Calhoun, The Question of Class Struggle, pp. 45-55. But see D. Thompson, "Women and Nineteenth-Century Radical Politics: A Lost Dimension", in: The Rights and Wrongs of Women, ed. by J. Mitchell and A. Oakley (Harmondsworth, 1976), p. 114, for the broad spectrum of radical ideas.

121 Thompson, The Making, pp. 913-15; Thompson, The Chartists, pp. 111-12. 
tury, to envisage a new and revolutionary way of re-establishing the moral social order as they saw it, and in doing so to become social innovators and revolutionaries. ${ }^{122}$

And, as Thompson has observed, from the 1830's onwards workers were less opposed to the new means of production than to the form which economic growth had taken; overriding concern now rested with attempts to "exert the collective power of the class to humanize the environment". ${ }^{123}$

Secondly, growing economic antagonisms between workers and capitalists during the Chartist years were one feature of a much wider picture of class divisions and class feeling. As Dorothy Thompson, Hollis, Epstein, Cunningham and Storch have shown, class conflict saturated life both inside and outside work. According to Dorothy Thompson, the middle classes "certainly believed themselves to be superior in every way to the classes above and below them in morality, knowledge and understanding." 124 And "Class domination was not confined to the work-place. All aspects of social life - dwelling-places, shops, drinking-places, recreational and instructional institutions, churches and chapel seating - were segregated on class lines." 125 The vast majority of middle-class people viewed workers with a mixture of fear and disgust: the latter were seen as animalistic, "without souls, minds, or culture", "fierce", "rough", "undisciplined", lacking "restraint", intemperate and improvident, easily led and given to riot and subversion. ${ }^{126}$ As Storch has written,

Everywhere one looks in the contemporary literature of description of the working classes at liberty or at play, and of their habits and customs, it is nearly impossible to take leave of a universe of discourse which reflected a profound sense of fear and disgust, coupled with muffled - and not so muffled - intimations of social catastrophe. ${ }^{127}$

And middle-class attempts to transform - by means of a whole battery of cultural institutions and practices - the character structures of workers and to channel them into the paths of acquisitiveness, individualism, competition, self-help, and "natural" acceptance of a state of subordination and

122 E. J. Hobsbawm, "Artisan or Labour Aristocrat?", in: Economic History Review, Second Series, XXXVII (1984), p. 362. For an excellent discussion of the dynamic character of artisan thought, especially the transformation from customary to more forward-looking goals, see Prothero, Artisans and Politics, op. cit., Conclusion.

${ }_{123}$ Thompson, The Making, p. 913.

124 Thompson, The Chartists, p. 240.

125 Ibid., p. 253.

126 Ibid., pp. 245-51; R. D. Storch, "The Problem of Working-Class Leisure”, in: Social Control in Nineteenth Century Britain, ed. by A. P. Donajgrodzki (London, 1977), pp. 139-42.

127 Storch, "Working-Class Leisure", p. 138. 
dependency met with the opposition of Chartist men and women. ${ }^{128}$ "With democracy and freedom upon their lips", thundered O'Connor of the League manufacturers, "do we not find them foremost, as masters, as magistrates, and as jurors, in persecuting all who dare to express opinions at variance with those by which they hope to accomplish their object?" ${ }^{29}$ It was the sheer hypocrisy of many of the middle class - their supposed beliefs in freedom and independence, and their treatment of workers as slaves and dependents - which so angered O'Connor, McDouall and many others. The response of the Chartists was to attempt to build an alternative "movement culture", free from the patronising and unwelcome attentions of both bourgeois and aristocrat. Concerns with personal dignity and independence, with the dignity of labour, with co-operative forms of activity, with honesty, trust and open, democratic practices and, above all, with an unbending faith in the ability of workers to fashion their own destinies these were the essential features of Chartism's alternative way of life. Class thus informed a whole culture, an entire way of life. ${ }^{130}$

Thirdly, given the profound and widespread class divisions of the Chartist period, it is difficult to see how the political changes outlined by Stedman Jones could have constituted a sufficient basis for the development of reformism. Nagging economic, political, social and cultural class conflicts ensured that the movement into reformism was far less smooth and untroubled, and involved a sharper break in working-class consciousness (as seen especially in the shelving of the more anti-capitalist ideas of the Chartists) than Stedman Jones allows. ${ }^{131}$

Fourthly, a serious question mark must be set against Stedman Jones's claim that the key to Chartism's decline lay in the mellowed character of the State from the early and mid 1840's onwards. Indeed, given its centrality to Stedman Jones's thesis, the nature and character of the mid-Victorian State merits far more detailed attention than it is possible to provide in this article. Some brief observations must suffice. As suggested by Saville, the mass political discontent and movements of the 1830's and early 1840's did provoke "a revision of social and political policies which moderated the harshness of existing legislation and which drew attention to a range of social problems subsumed under the general heading of 'The Condition of

128 E. Yeo, "Culture and Constraint in Working-Class Movements, 1830-1855", in: Popular Culture and Class Conflict 1590-1914, ed. by id. and S. Yeo (Brighton, 1981), pp. 157-60; Thompson, The Chartists, p. 251.

129 The Trial of Feargus O'Connor, p. vi.

130 J. A. Epstein, "Some Organisational and Cultural Aspects of the Chartist Movement in Nottingham", in: The Chartist Experience.

131 For continued class conflict in the mid-Victorian years see Kirk, Working Class Reformism, pp. 245-72. 
England"'. ${ }^{132}$ The Factory Acts, increased concern with public health and the provision of mass education, the decision not to mount a show trial at Lancaster in 1843 and the leniency afforded to O'Connor and the other defendants, and the quickened efforts of both Conservatives and Liberals to attract popular support - all indicated a heightened awareness on the part of the organs of State and sections of the ruling class of the need to offer sections of the working class a "stake in society", a "feeling that they are understood". ${ }^{133}$ It is, however, highly questionable as to whether such instances of "liberalization" amounted to the fundamental process of political change claimed by Stedman Jones. In order to successfully demonstrate his thesis, Stedman Jones would certainly have to make a far more substantial empirical case than is presented in his essays on Chartism. Only three and five pages of, respectively, "The Language of Chartism" and "Rethinking Chartism" are devoted to a concrete examination of State policy during the 1840 's, and this examination is heavily dependant upon the work of Richards. ${ }^{134}$ In sum, Stedman Jones's large claim concerning the changed role of the State is erected upon insubstantial empirical supports.

There exists, furthermore, solid evidence to suggest that changes in State policy were generally much more complex and uneven, and, in some instances, much less pronounced than suggested by Stedman Jones. It is, ironically, interesting to record in this context Stedman Jones's warning in the mid 1970's against an exaggerated acceptance of the concessions associated with "liberalization". ${ }^{135}$ Concrete changes in State policy and practice frequently failed to match shifts in sentiment, awareness and stated intention. The extension of the franchise awaited prolonged and clear demonstration of the characteristics of "Rochdale Man"; the legal recognition of trade unionism arrived only in the 1870 's; the mellowing of Conservatism and Liberalism was arguably less substantial than often maintained; and the vast majority of employers remained in opposition to trade-union recognition. ${ }^{136}$ And in relation to social policy, and especially government policy towards Ireland, the "high moral tone of the proceedings of the goverment" constituted a poor, indeed disgraceful, substitute for effective and humanitarian action. As Saville has observed,

132 J. Saville, "A Commentary by Way of Conclusion", in 1848: The British State and the Chartist Movement (forthcoming). Much of the following section concerning the character of the State is heavily indebted to John Saville's work.

133 See, for example, Kirk, Working Class Reformism, pp. 148-154, 164-65, 182-89, 336.

134 P. Richards, "State Formation and Class Struggle, 1832-48", in: Capitalism, State Formation and Marxist Theory, ed. by P. Corrigan (London, 1980).

135 Stedman Jones, Languages of Class, p. 73.

136 Kirk, Working Class Reformism, pp. 25, 31, 267-69. 
The Whig policy towards the Irish famine, as carried out by Trevelyan, can hardly be accounted as an abandonment of "aggressive liberalism", and with the exception of the prohibition of women and children underground in coal mines and the Factory Acts, there was notably little change in the workings of social policy. There was great disquiet over the vigorous reactions of working-class communities to the New Poor Law in the West Riding and Lancashire; [ . . ] but it cannot be argued that anything changed in the ways in which the Poor Law was being operated. [ . . . The actual workings of the Poor Law remained harsh and unpleasant, but its subjects were now mainly those who have never been able to make their problems articulate: the sick, the aged, one-parent families, orphan children, and those with physical or mental disabilities. Similarly, although there was massive documentation of the appalling conditions of the industrial towns in the 1840 's, the implementation of Chadwick's "Sanitary Idea" - the public cleansing of streets and courts, the proper disposal of night soil, and the provision of adequate supplies of clean water - was to take several decades before elementary standards were achieved on a national scale. ${ }^{137}$

In his excessive desire to concentrate our focus on the softened character of the State, Stedman Jones has also failed to alert us to the great extent to which coercion continued to be an essential feature of State policy in relation to popular "unrest" during the 1840 's. As Saville has remarked, "Stedman Jones has considered only the politcal and social changes in attitudes during the 1840's, and has omitted the more important actions of the State in the effective exercise of its coercive powers." 138 During those periods when mass agitation was most intense - 1839-40, 1842 and the spring and summer months of 1848 - the State did not hesitate to employ the necessary force to defeat Chartists, Irish revolutionaries and strikers. For example, the scale of repression which followed the strikes of 1842 was "probably unmatched in the nineteenth century". ${ }^{139}$ As Dorothy Thompson has written,

1842 was the year in which more energy was hurled against the authorities than in any other of the nineteenth century. More people were arrested and sentenced for offences concerned with speaking, agitating, rioting and demonstrating than in any other year, and more people were out on the streets during August 1842 than at any other time. ${ }^{140}$

And repression was highly effective in depriving, either temporarily or permanently, popular movements of much of their leadership and in greatly

138 Ibid., p. 27.

139 Jenkins, The General Strike of 1842, p. 219.

140 Thompson, The Chartists, p. 295. 
weakening morale and the wish to continue the struggle. Saville's comments penetrate to the heart of the matter.

The turbulent events of $1839-40,1842$ and 1848 each evoked similar reactions: cool, ruthless calculation with not much evidence of high moral tone. South Wales never recovered after 1840 , nor did the Potteries after 1842; and neither Scotland nor the Midlands were prominent in 1848. What happened in these three main periods of repression was that while some national leaders moved away [ . . . ] more important was the elimination of sections of the middle-range leadership; and most of those who suffered prison sentences did not return to the movement. The convictions of the summer and autumn of 1848 effectively neutralised a large part of the local and regional leaderships in London and the industrial North, and the general situation of the early 1850 s was not conducive to their revival, or to the generation of new cadres of militants. ${ }^{141}$

Such timely reminders as to the importance of coercion in the defeats suffered by working people during the 1840's should act as a necessary corrective to the idealised picture of the State painted by Stedman Jones. Some modifications in various aspects of State policy probably did follow mass agitation, but changes were far from complete and straightforward. Coercion and persuasion were both vital instruments in the maintenance of the status quo. And was it not often the case that softened State practice followed in the wake of highly effective repressive activity, at precisely that point in time when workers had been defeated and when the State had little to lose and everything to gain (in terms of its claims to neutrality and fairness) in striking a more sympathetic and accommodative pose? This is, for example, surely what happened in 1842 and 1843 when the volte-face at Lancaster Assizes followed the mass arrests and imprisonments of the previous year, and when $O^{\prime}$ Connor and the judge came to accept a common definition of legitimate political action. ${ }^{142}$ In any event the continued importance of coercion in the 1840 's counsels against both an exaggerated picture of changes in the character of the State and, ipso facto, against the key role of the State in the decline of Chartism.

To conclude. Full support has been given to Stedman Jones's opposition to economic reductionism, his emphasis upon the complexity of social interaction, his eschewal of preconceived notions of Chartist consciousness, and his refreshing aim to give proper attention to the study of politics and language. Simultaneously, however, this article has suggested that, in his non-referential approach to language and in his refusal to make "any simple prejudgement about the determining role of the social", Stedman 
Jones has effectively greatly underestimated the pressures and limits exerted by economic and social factors (and especially the development of capitalist structures and practices) upon the thinking of Chartism. In "The Language of Chartism" and "Rethinking Chartism" language and politics have been improperly wrenched loose from their material determinations. As a result the class-based character of Chartism has been falsely denied. Stedman Jones's rejection of a class-based reductionism has led not to materialism, but to an unconvincing idealism. ${ }^{143}$

${ }^{143}$ John Foster and Ellen Wood have both criticised the idealist thrust of Stedman Jones's recent work. See Foster, "The Declassing of Language", pp. 40-45; E. M. Wood, The Retreat From Class (London, 1986), pp. 102-15. 